\title{
WestVirginiaUniversity
}

THE RESEARCH REPOSITORY @ WVU

Graduate Theses, Dissertations, and Problem Reports

2006

\section{High school football player's nutritional knowledge and application}

Kimberly A. Molnar

West Virginia University

Follow this and additional works at: https://researchrepository.wvu.edu/etd

\section{Recommended Citation}

Molnar, Kimberly A., "High school football player's nutritional knowledge and application" (2006). Graduate Theses, Dissertations, and Problem Reports. 2365.

https://researchrepository.wvu.edu/etd/2365

This Thesis is protected by copyright and/or related rights. It has been brought to you by the The Research Repository @ WVU with permission from the rights-holder(s). You are free to use this Thesis in any way that is permitted by the copyright and related rights legislation that applies to your use. For other uses you must obtain permission from the rights-holder(s) directly, unless additional rights are indicated by a Creative Commons license in the record and/ or on the work itself. This Thesis has been accepted for inclusion in WVU Graduate Theses, Dissertations, and Problem Reports collection by an authorized administrator of The Research Repository @ WVU. For more information, please contact researchrepository@mail.wvu.edu. 
High School Football Player's Nutritional Knowledge and Application

\author{
Kimberly A. Molnar \\ Thesis submitted to \\ School of Physical Education \\ at West Virginia University in \\ partial requirement for fulfillment \\ of the degree of
}

Master of Science

In

Athletic Training

Dr. Michelle A. Sandrey, PhD, ATC

Dr. Cindy Fitch, Ph.D., RD

Dr. Ruth Kershner EdD, RN, CHES

School of Physical Education

Morgantown, WV

2006

Key words: adolescent, nutritional knowledge, nutritional application, football athletes 


\title{
ABSTRACT
}

High School Football Player's Nutritional Knowledge and Application.

\author{
Kimberly, A. Molnar
}

Context: Nutrition plays a vital role in the health of the athlete, especially football athletes. Studies have shown that high school football players lack the application of any nutritional knowledge that they may have, predisposing them to injury or illness. Objective: The purpose of this study is to determine the nutritional knowledge of high school football players and to determine the application of this knowledge through their food choices. Design: A prospective descriptive analysis of the nutritional knowledge of high school football players by year in school and the actual application of this nutritional knowledge through a diet recall. A $1 \times 4$ factorial design was used for the scores on the nutritional knowledge questionnaire and year in school. A $4 \times 5$ factorial design was used for year in school and the five groups of the questions. A $1 \times 4$ factorial design was used for year and school and the questions on the diet recall. Setting: A rural class AA high school in north central West Virginia. Patients and Other Participants: A total of 57 varsity, junior varsity, and freshman football players completed the nutritional knowledge questionnaire and diet recall. Interventions: A 9-item demographic questionnaire, a 27item nutritional knowledge questionnaire and a 15 question diet recall was distributed to the football players of a north central West Virginia high school. Main Outcome Measures: The nutritional knowledge questionnaire scores will be low (below 70\%). There will be a difference between year in school and the scores on the nutritional knowledge questionnaire as well as for the five groupings. The diet recall will show a lack of proper nutrition choices. Results: A total of $56.1 \%$ participants $(n=32)$ answered 17 or more questions correctly on the nutritional knowledge questionnaire. There was a significant difference between the number correct on the nutritional knowledge questionnaire and year in school $\left(\mathrm{F}_{1,3}=4.858, \mathrm{P}=.005, \beta=.885\right)$, between freshman and sophomores $(\mathrm{P}=.006)$. There was a significant difference between the number correct on the nutritional knowledge questionnaire and between the five groupings; Group 1 $\left(\mathrm{F}_{1,3}=3.983, \mathrm{P}=.012, \beta=.808\right)$, Group $3\left(\mathrm{~F}_{1,3}=3.616, \mathrm{P}=.019, \beta=.765\right)$, and Group 4 $\left(\mathrm{F}_{1,3}=4.978, \mathrm{P}=.004, \beta=.893\right)$. There was a significant difference found between the number answered correctly for Group 1 between the freshman and sophomores $(\mathrm{P}=.011)$, for Group 3 between the freshman and sophomores $(\mathrm{P}=.015)$, and for Group 4 between the sophomores and juniors $(\mathrm{P}=.044)$, and between the juniors and seniors $(\mathrm{P}=.004)$. All other results were not significant. A significant difference was found between year in school and responses for question number seven on the diet recall $\left(\mathrm{F}_{1,3}=3.991, \mathrm{P}=.012\right.$, $\beta=.809)$ between freshman and seniors $(\mathrm{P}=.024)$, and juniors and seniors $(\mathrm{P}=.039)$. Conclusion: High School football players lack proper nutrition knowledge, even though they are receiving nutrition education in health class. These athletes lack the knowledge about the Food Guide Pyramid and servings for each group and what constitutes as proper serving sizes. They are also not applying any knowledge that they do have when making food choices.

Key Words: adolescent, nutritional knowledge, nutritional application, football athletes. 


\section{ACKNOWLEDGEMENTS}

First and foremost, I would like to thank Dr. Sandrey for all of her time and effort. You have been such a huge help to me, from helping me find sources, to fixing my disk problems. Thank you so much for Everything!!

I would also like to thank Dr. Fitch and Dr. Kershner for being on my committee and for all of the help and input you have given me on my thesis.

I would like to say thank you to the athletic director, football coaches, and players for allowing me to conduct this study at their school.

I would also like to thank my parents and grandparents for all of their love and support. You believed in me even when I didn't believe in myself. Thank you so much for Everything!!

A big thank you goes to all of my friends. Without all of you, I never could have done it! Thanks for all of your support.

Finally, I would like to thank Fred. You have been there with me every step of the way. Thank you so much for all of your love and support! 


\section{TABLE OF CONTENTS}

ACKNOWLEDGEMENTS ....................................................ii

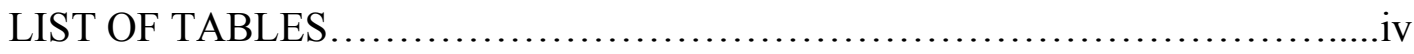

LIST OF FIGURES.................................................vii

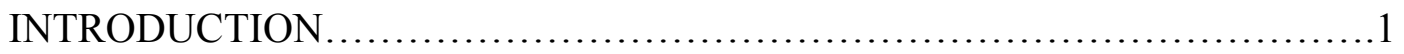

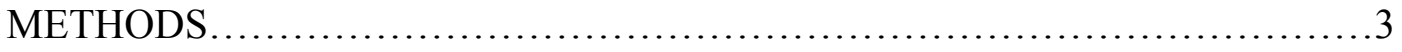

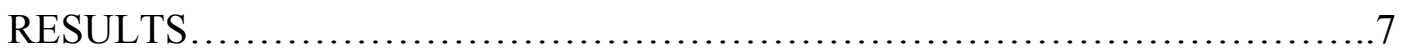

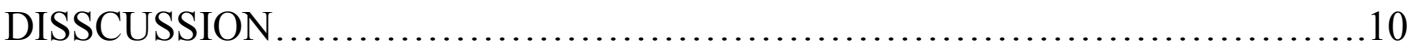

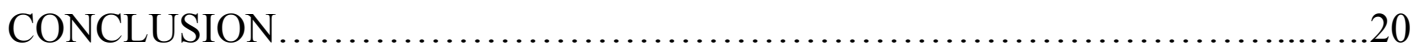

REFERENCES .......................................................... 22

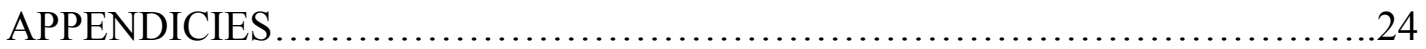

APPENDIX A: THE PROBLEM.................................25

APPENDIX B: LITERATURE REVIEW ............................. 31

APPENDIX C: ADDITIONAL METHODS...............................55

APPENDIX D: ADDITIONAL RESULTS..........................63

APPENDIX E: RECCOMMENDATIONS FOR FURTHER RESEARCH...79

ADDITIONAL REFERENCES............................................ 80 


\section{LIST OF TABLES}

Table

B1. Fat-Soluble Vitamins.............................................. 34

B2. Water-Soluble Vitamins......................................... 35

B3. Major Minerals..................................................... 35

B4. West Virginia Nutrition Standards Grades 6 through High School.............45

B5. Interests of Nutrition Topics by Collegiate Football Players..................48

B6. Dietary Assessment Methods........................................50

C1. Cover Letter..................................................... 55

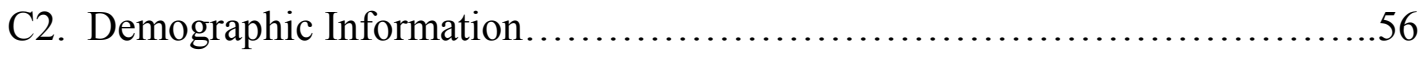

C3. Nutritional Knowledge Questionnaire.....................................................57

C4. Diet Recall....................................................6 60

D1. Descriptive Statistics for the Total Correct.............................63

D2. ANOVA Results for the Total Correct on the Nutritional Knowledge

Questionnaire........................................................63

D3. Tukey Post Hoc Results for the Total Correct on the Nutritional Knowledge Questionnaire.......................................................63

D4. Descriptive Statistics for the Total Correct of the 5 Groupings...............63

D5. MANOVA Results for the Total Correct of the 5 Groupings................64

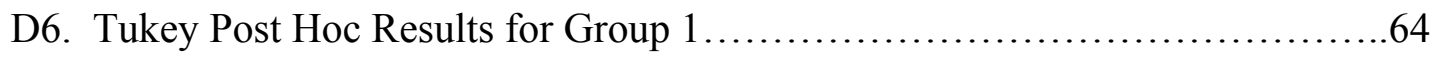

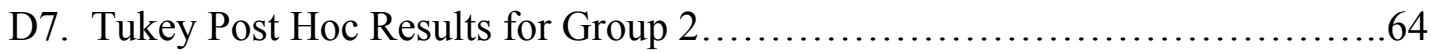

D8. Tukey Post Hoc Results for Group 3 .................................64

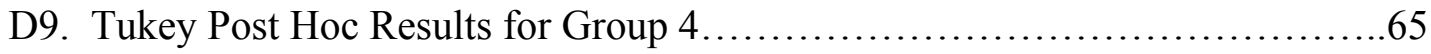

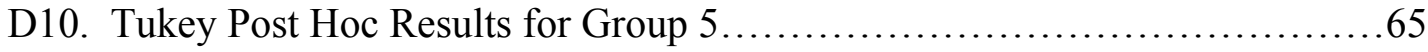


D11. MANOVA Results for the Diet Recall Questionnaire..........................65

D12. Tukey Post Hoc Responses for Diet Recall Question 1........................66

D13. Tukey Post Hoc Responses for Diet Recall Question 2.......................66

D14. Tukey Post Hoc Responses for Diet Recall Question 3.......................66

D15. Tukey Post Hoc Responses for Diet Recall Question 4........................66

D16. Tukey Post Hoc Responses for Diet Recall Question 5........................67

D17. Tukey Post Hoc Responses for Diet Recall Question 6........................67

D18. Tukey Post Hoc Responses for Diet Recall Question 7 .........................67

D19. Tukey Post Hoc Responses for Diet Recall Question 8 ........................67

D20. Tukey Post Hoc Responses for Diet Recall Question $9 \ldots \ldots \ldots \ldots \ldots \ldots \ldots \ldots \ldots \ldots . \ldots 6$

D21. Tukey Post Hoc Responses for Diet Recall Question 10.......................68

D22. Tukey Post Hoc Responses for Diet Recall Question $11 \ldots \ldots \ldots \ldots \ldots \ldots \ldots \ldots \ldots . \ldots 6$

D23. Tukey Post Hoc Responses for Diet Recall Question 12 .......................68

D24. Tukey Post Hoc Responses for Diet Recall Question 13........................69

D25. Tukey Post Hoc Responses for Diet Recall Question 14_.......................69

D26. Tukey Post Hoc Responses for Diet Recall Question 15.......................69

D27. Responses to Diet Recall Questions 1-15.................................70 


\section{LIST OF FIGURES}

Figure

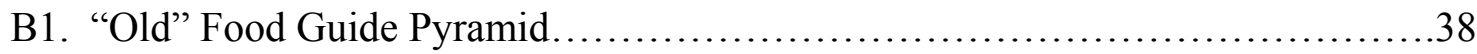

B2. Serving Sizes for the "Old" Food Guide Pyramid............................... 38

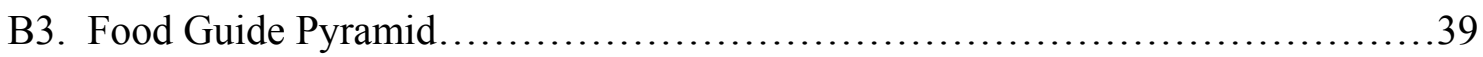

B4. Food Guide Pyramid Serving Sizes........................................39

D1. Responses to Diet Recall: 100\% Fruit Juice (Question 1) .................... 71

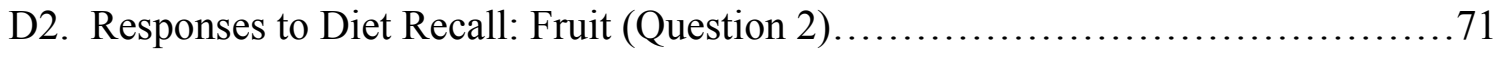

D3. Responses to Diet Recall: Salad (Question 3) ............................ 72

D4. Responses to Diet Recall: Potatoes (Question 4)...........................72

D5. Responses to Diet Recall: Carrots (Question 5)............................ 73

D6. Responses to Diet Recall: Other Vegetables (Question 6).....................73

D7. Responses to Diet Recall: Glasses of Milk (Question 7)......................74

D8. Responses to Diet Recall: Chicken, Fish, or Red Meat (Question 8)..............74

D9. Responses to Diet Recall: Other Types of Protein (Question 9)................. 75

D10. Responses to Diet Recall: Bread or Cereal (Question 10).....................75

D11. Responses to Diet Recall: Other Types of Grains (Question 11)...............76

D12. Responses to Diet Recall: Fast Food (Question 12)...........................76

D13. Responses to Diet Recall: Glasses of Soda (Question 13)....................77

D14. Responses to Diet Recall: Junk Food (Question 14) ......................77

D15. Responses to Diet Recall: Water (Question 15)...........................78 


\section{INTRODUCTION}

Nutrition plays a vital role in the health of athletes. Lack of nutritional knowledge can lead to poor eating habits which can then affect the performance of the athlete. The American Dietetic Association (ADA) recommends that adolescent athletes in organized sports engage in healthful and balanced nutrition practices that promote optimal growth along with performance. ${ }^{1}$ However, the average adolescent athlete does not consume the adequate nutrients necessary for a well balanced diet. ${ }^{2}$

Football athletes have the least nutritional knowledge of all of the other sports. As based on other studies, the adolescent athlete does not score any better on nutritional knowledge than their non-athlete counterpart..$^{3,4,5,6}$ In a study done by Mitchell ${ }^{3}$ on high school athletes nutritional knowledge in a small school in Pennsylvania, football athletes averaged 13.57 out of a possible 27 points compared with the total average (15.07) for all the males at the school. Females completing a survey and food pattern document received high scores (average 105 out of a possible 155) on the nutrition survey when talking about nutrition for the athlete, but lower $(<30 \%$ correct $)$ on the parts regarding basic nutrition. ${ }^{4}$ Pirouznia ${ }^{5}$ also reported similar results with adolescent girls scoring higher than boys on nutrition surveys. The girls had an average score of 12.35 compared to the boys with an average score of only 10.86 out of a possible 20 points. Another study done by Schmaltz ${ }^{6}$ indicated similar results implicating bad habits regarding diet and nutrition using a questionnaire about basic nutrition information. This study of 381 high school students found that $61 \%$ of the students ate a lunch high in fat. The good news about nutritional knowledge among adolescents is that the majority of the 
participants from these studies expressed the need and desire for more education on nutrition throughout high school.

High school football players need to become better educated on proper nutrition to apply this knowledge into their own lifestyles. Few studies ${ }^{7,89}$ have been completed on athletes and their application of nutrition. In addition only three studies ${ }^{7,8,9}$ on adolescents actually reported results from the questionnaire instead of focusing on validity and reliability of the questionnaire format and type of study, whether prospective or retrospective. The diet for the average adolescent is comprised of mostly junk food, with little to no vegetables and fruit. ${ }^{3}$ Poor diet choices in studies were related to intake of more soft-drinks and pre-sweetened foods and beverages. One such study was done by Frary ${ }^{7}$ using the United State Department of Agriculture's (USDA) CSFII survey. This study concluded that consuming high amounts of pre-sweetened foods and beverages and more soft-drinks decreases the rates of meeting the Recommended Daily Allowance (RDA) values for all nutrients. Speck ${ }^{8}$ also concur with these results as he completed a study using a modification of the Eating Habits Questionnaire (EHQ) specifically designed for adolescents. Results from his study, involving 446 middle school students, indicated that adolescents consumed higher than recommended daily servings for fats, sweets, and meats and lower than recommended servings of vegetables and breads. ${ }^{8} \quad$ Whole grain consumption has also been decreasing over the years. Harnack $^{9}$ found through her study of 4,802 high school students, that the mean average of consumed whole grains was only one serving a day. This is very low compared to the Food Guide Pyramid's recommendation of at least 3 servings of whole grains per day. ${ }^{10}$ 
This type of diet leaves little room for the essential nutrients necessary for sport participation.

There is an important need to evaluate the knowledge and eating habits of adolescent football athletes to understand the request for further nutrition education. As can be seen from the studies reported, football players do score lower when compared to other athletes or the adolescent population on nutritional knowledge questionnaires. In addition only three studies ${ }^{7,89}$ reported high-quality findings from diet recall questionnaires using an adolescent population. To the authors knowledge there have not been any studies that looked at nutritional knowledge and diet recall in football athletes. High school football players lack the application of any nutrition knowledge that they may have, setting them up for injury or illness. ${ }^{2}$ Once nutritional knowledge is reviewed, then nutritional application should be explored through the actual food choices of football athletes. Therefore, the purpose of this study is to determine the nutritional knowledge of high school football players and to determine the application of this knowledge through their food choices.

\section{METHODS}

The design of this study was a prospective descriptive analysis, which identifies the nutritional knowledge of high school football players by year in school through the use of a nutritional knowledge questionnaire. It also identified the actual application of this nutritional knowledge through a diet recall. A 1x4 factorial design was used to compare the nutritional knowledge questionnaire scores with the year in school (freshman, sophomore, junior, senior). The dependent variable was the score on the nutritional knowledge questionnaire. Another $4 \times 5$ factorial design was used to compare 
year in school with the five groupings (grains and meat and beans, fruits and vegetables, vitamins and minerals, diet, and hydration). The independent variable was the year in school by the five groupings. The dependent variable is the scores on the five groupings. For this study, it was determined that to be knowledgeable on the nutritional knowledge questionnaire the participants needed to score a $70 \%$ or better (18.9 out of a possible 27 ). A $1 \times 4$ factorial design was used to compare year in school and the questions on the diet recall. For the diet recall the independent variable is year in school, while the dependent variables for the responses to the diet recall questions.

Participants

The participants for the study were 57 football players from a four-year rural high school in north central West Virginia. This was a $100 \%$ response rate. The average age was $15.44 \pm 1.12$ years old. All of the participants were males on the high school football team, competing at the varsity, junior varsity, and freshman level (24 Freshman, 13 Sophomores, 11 Juniors, and 9 Seniors). The average number of years the participants played football was $5.07 \pm 2.56$ years. The high school principal, athletic director and the football coaches granted permission to use these football athletes at the high school. The study was approved by the Institutional Review Board (IRB) for the Protection of Human Participants, at West Virginia University. Instrumentation

The nutritional knowledge questionnaire consisted of 8 demographic questions and 27 questions for nutritional knowledge consisting of multiple-choice $(\mathrm{n}=13)$ and true/false ( $\mathrm{n}=14)$ questions. The questions were divided into sections, which represent information related to: 1) carbohydrates and proteins; 2) fruits and vegetables; 3 ) 
vitamins and minerals; 4) diet; and 5) hydration. This questionnaire was developed from a similar study evaluating the nutritional knowledge of high school athletes by Mitchell. ${ }^{3}$ Face and content validity of the questionnaire was established in that study. The content of this questionnaire was based on general knowledge, which the football players have covered in their high school health class according to the state standards.

The diet recall was a documentation of the actual application of the football players' nutritional knowledge. It consisted of 15 multiple choice questions regarding particular foods that were consumed within the last seven days. The diet recall contains questions that were a modification of the nutritional section of the 2005 Youth Risk Behavior Survey that is completed each year by the Centers for Disease Control and Prevention. ${ }^{11}$ The diet recall answers were based on the 1996 Food Guide Pyramid, since the participants obtained information from health class using the previous guidelines. One registered and licensed dietitian examined the questionnaire and diet recall for clarity, order, and selections, as well as for content and face validity. The diet recall was also viewed by four certified athletic trainers who have nutrition knowledge and experience working with high school athletes, and by three high school studentathletes for clarity, and wording as well as for content and face validity.

Procedures

Questionnaires were distributed to the football players at a Class AA high school in north central West Virginia. A cover letter (Table C1) was included to explain the purposes of the study to the participants and to indicate their rights as participants. The demographic questions (Table C2), nutritional knowledge questionnaire (Table C3), and diet recall (Table $\mathrm{C} 4$ ) were distributed to the athletes on an assigned day. The cover 
letter and directions were read aloud while the participants read along. After the directions were read, time was allotted for the participants to complete the study. After completing both questionnaires and the diet recall, the participants were asked to place them in a labeled envelope in the front of the room. The primary investigator collected the envelope after the participants left the room.

Data Analysis

For data analysis, the nutritional knowledge questions were divided into five groups to reflect the areas of general nutritional knowledge that the students should have retained from health class. Questions 1-8 were in the carbohydrate and protein group. The fruits and vegetable group consisted of questions 9-13. Questions 14-17 consisted of the vitamin and mineral group. The diet group had questions 18-23 and question number 27. The remaining questions $24-26$ comprised the hydration group. These five groupings were analyzed compared to year in school.

Statistical Analysis

Descriptive statistics were used to analyze the data that was collected from the nutritional knowledge questionnaire, diet recall, and the demographic information. Means, standard deviations, and percentages of responses received were calculated. A one-way analysis of variance (ANOVA) was used to determine the differences between year in school with the number of correct responses on the questionnaire. A two-way multivariate analysis of variance (MANOVA) was used to determine the differences between year in school with the five groupings on the questionnaire. The means, standard deviations, and percentages of responses received from the diet recall were calculated. A one-way MANOVA was used to determine the difference between year in 
school and the responses on the diet recall. The $\mathrm{P}$ value was set at $\mathrm{P} \leq 0.05$ for all analyses.

\section{RESULTS}

Demographic Information

A total of 57 participants completed the nutritional knowledge questionnaire. The average age was $15.44 \pm 1.12$ years. All of the participants were males on the high school football team, competing at the varsity, junior varsity, and freshman level. Forty-two and one tenth percent $(n=24)$ of the participants were Freshman, $22.8 \%(n=13)$ were Sophomores, $19.3 \%(n=11)$ were Juniors, and 15.8\% $(n=9)$ were Seniors. The average number of years the participants played football was 5.07 \pm 2.56 years. Eighty-seven and seven tenths percent $(n=50)$ of the participants said they learned about nutrition in health class. When asked, $78.9 \%(n=45)$ of participants said they ate breakfast on most days. There were $96.5 \%(n=55)$ of the participants who ate school lunches everyday. The participants were asked how many meals and snacks that they consumed a day. The results indicated that the average meals per day were $3.24+.79$ meals and the average number of snacks was 3.09 \pm 2.82 snacks per day. Nutritional Knowledge Questionnaire

Descriptive statistics for the total number correct on the nutritional knowledge questionnaire by year in school are found in Table D1. A total of 56.1\% participants $(n=32)$ answered 17 or more questions correctly on the nutritional knowledge questionnaire. The mean score on the nutritional knowledge questionnaire was $16.49 \pm 3.6$, with a range from 8 to 23 questions answered correctly. The sophomores scored the highest with an average of $19.00 \pm 2.68$. There was a significant difference 
between the number correct on the nutritional knowledge questionnaire and year in school $\left(\mathrm{F}_{1,3}=4.858, \mathrm{P}=.005, \mathrm{~B}=.885\right)$, between freshman and sophomores $(\mathrm{P}=.006)$. On the nutritional knowledge questionnaire for total correct sophomores scored higher $(19.00 \pm 2.68)$ than freshman $(15.08 \pm 2.89)$. Additional results are found in Tables D2 to D3.

The mean score for the carbohydrates and protein group (Group 1) was $3.77 \pm 1.4$ out of $8,2.58 \pm 1.1$ out of 5 for the fruits and vegetables group (Group 2), 2.26 \pm 1.0 out of 4 for the vitamins and minerals group (Group 3), $5.61 \pm 1.5$ out of 7 for the diet group (Group 4), and 2.25+.85 out of 3 for the hydration group (Group 5). Additional results are found in Table D4. There was a significant difference between the number correct on the nutritional knowledge questionnaire and between the five groupings: for Group 1 $\left(\mathrm{F}_{1,3}=3.983, \mathrm{P}=.012, \beta=.808\right)$, Group $3\left(\mathrm{~F}_{1,3}=3.616, \mathrm{P}=.019, \beta=.765\right)$, and Group 4 $\left(\mathrm{F}_{1,3}=4.978, \mathrm{P}=.004, \beta=.893\right)$. The results were not significant for Group $2\left(\mathrm{~F}_{1,3}=2.256\right.$, $\mathrm{P}=.093, \beta=.539)$ or Group $5\left(\mathrm{~F}_{1,3}=.470, \mathrm{P}=.704, \beta=.139\right)$. There was a significant difference found between the number answered correctly for Group 1 between the freshman and sophomores ( $\mathrm{P}=.011)$, for Group 3 between the freshman and sophomores $(\mathrm{P}=.015)$, and for Group 4 between the sophomores and juniors $(\mathrm{P}=.044)$, and between the juniors and seniors $(\mathrm{P}=.004)$. In Group 1 sophomores scored higher than the freshman with a score of $4.62 \pm 1.45$ compared to $3.21 \pm 1.06$. In Group 3 sophomores again scored higher than the freshman with a score of $2.92 \pm .95$ compared to $1.88 \pm .89$. In Group 4 sophomores scored higher than the juniors with a score of $6.08 \pm 1.19$ compared to $4.55 \pm 1.92$ and the seniors scored higher than the juniors with a score of $6.78+.67$. All other results were not significant. Additional results are found in Tables D5 to D10. 


\section{Diet Recall}

A total of 57 participants completed the diet recall to note whether the high school football athletes were consuming the appropriate nutrients and food groups in their diet. A significant difference was found between year in school and responses for question number seven on the diet recall $\left(\mathrm{F}_{1,3}=3.991, \mathrm{P}=.012, \beta=.809\right)$, for the freshman and seniors $(\mathrm{P}=.024)$, and the juniors and seniors $(\mathrm{P}=.039)$. All other results were not significant. Additional results are found in Tables D11 to D26.

Responses selected for the questions varied, from consuming the appropriate servings in the food guide pyramid to above and below that intake for the last seven days. Only the responses that were selected the most often by the participants will be reported here. Additional results can be found in Table D27. On question number one of the diet recall, $24.6 \%(n=14)$ of the participants drank $100 \%$ fruit juice $4-6$ times in the last seven days. During the past seven days, $26.3 \%(n=15)$ of the participants ate fruit 4-6 times. For responses on question number three of the diet recall, $29.8 \%(n=17)$ of the participants ate salad 1-3 times in the past seven days. Twenty-eight and one tenth percent $(n=16)$ of the participants ate potatoes 1-3 times in the last seven days, not including French fries, fried potatoes, or potato chips. On question number five, $36.8 \%$ $(n=21)$ of the participants did not eat carrots in the past seven days. The responses for question number six indicated that $31.6 \%(\mathrm{n}=18)$ of the participants ate other vegetables, not including salad, potatoes, or carrots, one time per day. Question number seven asked how many glasses of milk were drank in the last seven days. The responses indicated that $24.6 \%(n=14)$ of participants drank milk 4-6 times, while $24.6 \%(n=14)$ participants drank milk 2 times per day. Responses to question number eight indicated that $24.6 \%$ 
$(n=14)$ of the participants ate chicken, fish, or red meat one time per day. Question number nine asked about all other types of protein. Twenty-four and six tenths percent $(n=14)$ of the participants ate other types of protein 4-6 times in the last seven days. On question number ten, $22.8 \%(\mathrm{n}=13)$ of the participants ate bread/cereal 1-2 times a day. Other types of grain were eaten at least 1-3 times in the past week by $29.8 \%(n=17)$ of the participants according to responses to question number eleven. The responses for question number twelve indicated that $47.4 \%(n=27)$ of the participants ate fast food only 1-3 times during the past seven days. Thirty-one and six tenths percent $(n=18)$ of the participants drank only 1-3 glasses of soda during the past seven days for question number thirteen. Question number fourteen asked how many times the participants ate junk food in the past seven days with $26.3 \%(n=15)$ of participants eating junk food once a day or less. On question number fifteen, $17.5 \%(\mathrm{n}=10)$ of participants either drank water 4-6 times in the past seven days, 2 times $(17.5 \%, \mathrm{n}=10), 3$ times $(17.5 \%, \mathrm{n}=10)$, or 4 times $(17.5 \%, \mathrm{n}=10)$ per day. Additional results are found in Figures D1 to D15.

\section{DISCUSSION}

The purpose of this study was to determine the nutritional knowledge of high school football players and to determine the application of this knowledge through their food choices. The questionnaire was further broken down into five groupings and the number correct for the five different groups were analyzed by year in school. The diet recall allowed the participants to recall how often they consumed specific foods and beverages in the last seven days.

Demographic Information 
The results indicated that the majority of the participants ate breakfast and school lunches, which is comparable to other similar studies. Breakfast as part of a healthy diet and lifestyle can positively impact children's health and well-being. ${ }^{12}$ Compared to $78.9 \%$ of the participants in this study who ate breakfast, Buergel's ${ }^{12}$ study indicated that only $41 \%$ eat breakfast, while the remaining 59\% skip breakfast more than three times in a week. Other studies have also indicated that many high school students do not eat breakfast. Hickson's ${ }^{2}$ study indicated that only $19 \%$ of his participants ate breakfast and $81 \%$ skipped breakfast almost daily. Although, in one study $87 \%$ of participants said they ate breakfast on most days, $54 \%$ of those breakfasts were high in fat. ${ }^{6}$ By skipping breakfast, adolescents have already started off poorly and are missing out on the essential nutrients. $^{13}$

School lunches are very important when discussing adolescent nutrition and should provide these athletes with appropriate nutrients and healthy food for their day. Everyday there are approximately 27 million children in the United States that eat school lunch. ${ }^{26}$ This large number indicates the need for school lunches to be nutritionally sound meals that offer a variety of foods with good nutritional value. This study indicated that $96.49 \%$ eat school lunch on most days. This number was higher than a study that indicated $79 \%$ of adolescents eat lunch at school. ${ }^{14}$ Although not a part of this study, one study indicated that $61 \%$ of the participants that ate school lunches were lunches high in fat. ${ }^{6}$ In fact, only $26 \%$ of their study population reported eating nutritionally balanced lunches adhering closely to USDA recommended dietary standards. 
Other studies have indicated that adolescents have more control over their eating habits and more access to food outside the home, experiment more with food choices, deviate more from 3-meal-a-day eating patterns, and are more likely to snack. ${ }^{15}$ This study indicated that most of the participants stay within the normal 3-meal-a-day eating pattern with $3.24 \pm .79$ meals and an average number of snacks at $3.09 \pm 2.82$ per day. The results are similar to the recommended number of meals per day at three but the specified number of snacks to consume cannot be determined because there is no set recommendation for the number of snacks per day. ${ }^{10}$ Therefore, it may be difficult to determin in this study if consuming as many as 12 snacks for most days would be considered high. However the results of this study are comparable to a study by Dwyer et $\mathrm{al}^{14}$, in which $69 \%$ of participants ate at least three meals a day and ate an average of two snacks per day. Overall, the numbers reported in this study are fairly normal for adolescents today.

Nutritional Knowledge Questionnaire

It was hypothesized that high school football players would be knowledgeable about proper nutrition. The results in this study, however, indicated differently. The average score on the questionnaire was only $16.49 \pm 3.63(61.07 \%)$ out of a total of 27 questions. Other studies indicated similar findings. Mitchell ${ }^{3}$ found that the football athletes averaged $13.57 \pm 3.81$ on the same questionnaire. This was even lower than the overall male average of $15.07 \pm 2.16$. Pirouznia ${ }^{5}$ also reported similar results with the boys scoring lower on a nutritional knowledge questionnaire. The middle school boys had an average score of only $54.3 \%$ on the Comprehensive Assessment of Nutrition Knowledge, Attitudes, and Practices (CANKAP) test. However, in Werblow's study 
using 94 females to complete a survey and food pattern document, the participants received high scores (average 105 out of a possible 155) on the nutrition survey when talking about nutrition for the athlete, but lower $(<30 \%$ correct) on the parts regarding basic nutrition. Nutrition is a requirement that is covered in health class in West Virginia; however, the basic nutrition information regarding the Food Guide Pyramid and the serving sizes appears not to be retained over the years. Nutrition coursework is also a requirement in the state of Pennsylvania. However, the majority of subjects in Mitchell's ${ }^{3}$ study scored below $70 \%$ passing also. On-going education may be necessary for better understanding of the nutrition information with any high school athlete. It was also hypothesized that there would be a significant difference for total on the nutritional knowledge questionnaire between the year in school for the high school football players. This hypothesis was accepted because the results indicated that there was a difference between the freshman and sophomores. This could be due to the fact that West Virginia high school students take a health class that covers nutrition in their freshman year and most of the sophomores retained that information whereas the freshman might have not taken a health class yet. One study used 532 middle school students and reported that the $7^{\text {th }}$ graders scored higher (29.85 out of 30) on the CANKAP test than the $8^{\text {th }}$ graders (26.84 out of 30 ), showing that nutrition was not retained from the $7^{\text {th }}$ grade health class. ${ }^{5}$ Similar results were found in Mitchell's study. ${ }^{3}$ This particular study indicated that Pennsylvania students also take a health class their freshman year and have similar nutritional standards to that in West Virginia.

It was also hypothesized that there would be a difference for the total number correct of the five groupings between year in school among the high school football 
players. This hypothesis was also accepted because the results indicated that there was a significant difference in Groups 1, 3, and 4. In Group 1, the carbohydrate and protein group, and in Group 3, the vitamins and mineral group, there was a difference between the freshman and sophomores. The diet group, Group 4, indicated a difference between the sophomores and juniors, and between the juniors and seniors. These differences may be accounted for again based on the sophomores retaining the information from their health class they had taken freshman year.

The results from the groupings indicated that the participants were not knowledgeable about carbohydrates and proteins (Group 1) with an average score of 3.77 out of 8 , about fruits and vegetables (Group 2) with an average of 2.58 out of $8(32.25 \%)$, and about vitamins and minerals (Group 3) with an average score of 2.26 out of 4 (56.5\%). These results are very similar to those results from Mitchell's study. ${ }^{3}$ Her results indicated scores of $3.84 \pm 1.45$ for the carbohydrates and protein group, $2.54 \pm 1.13$ for the fruit and vegetable group, and $2.15 \pm 1.12$ for the vitamins and mineral group. This indicates that overall, adolescent athletes do not have proper nutritional knowledge regarding these topics. The results indicated that $71.93 \%$ of participants $(n=41)$, knew that the main source for energy for athletes was carbohydrates. However, only $35.09 \%$ of participants $(n=20)$, knew that carbohydrates and protein had the same caloric value. Mitchell ${ }^{3}$ found that athletes were misinformed or uneducated about the role of carbohydrates and protein in the body and what roles they play about health and performance. In this study $82.46 \%(n=47)$, of the football players wrongly believed that protein is the primary source of energy for muscles. These results were confirmed by Jonnagaladda, ${ }^{16}$ in which his study indicated that more than $50 \%$ of the athletes felt that 
protein was the primary energy source and high amounts of protein will increase muscle size. In this study, $68.4 \%(n=39)$ of participants thought that eating protein would increase muscle size. These beliefs, although common among adolescent males, need to be corrected by further education so that their eating habits do not reflect the improper knowledge.

Athletes need to have a good diet and be properly hydrated for practices and competitions. $^{3} \quad$ The participants did well on the diet (Group 4) and hydration (Group 5) sections. On the diet section, the average score was $5.61 \pm 1.52$ out of a possible 7 questions. The results indicated that $77.19 \%$ of participants $(n=44)$, knew that the types of food eaten does affect their athletic performance. The hydration group also scored high with an average score $2.25 \pm .82$ out of a possible 3 . There were $64.91 \%$ of participants $(n=37)$ that knew they should not rely on thirst to ensure proper fluid replacement. The emphasis on the importance of hydration lately may be the reason that the athletes are aware of proper hydration practices. Before each football season starts, the athletes watch a video emphasizing the importance of proper hydration and the dangers of heat illness. These numbers are high compared to that of Mitchell's results. ${ }^{3}$ Her study indicated that the average responses on the diet group was only $2.07 \pm 1.55$ and on the hydration group was only $1.73 \pm .78$. If more attention is placed on proper nutrition as well as hydration, the knowledge and habits of these athletes may improve as well. Diet Recall

It was hypothesized based on the diet recall responses; that high school football players do not apply their nutrition knowledge in everyday life. This hypothesis holds true, due to the fact that the responses on the diet recall were below the recommended 
serving sizes on the Food Guide Pyramid. Studies have shown that most adolescents do not meet dietary recommendations of the Food Guide Pyramid. ${ }^{17}$ Only about $1 \%$ of adolescent males and females met recommendations for all of the food groups, while 7\% of males did not meet any of the recommendations. ${ }^{17}$ This is an overwhelming indication that more education needs to emphasize the importance of proper diet and nutrition. Effective nutrition intervention and education strategies are needed to promote adoption of healthy eating behaviors.

It was also hypothesized that there will be a significant difference between the responses on the diet recall and year in school. The hypothesis was accepted only for question number seven on the diet recall between year in school for the freshman and seniors, and the juniors and seniors. Question number seven on the diet recall asked how many glasses of milk the participants drank in the last seven days. Only $17.54 \%$ of the participants $(\mathrm{n}=10)$, are getting the recommended servings of dairy per day. The serving sizes for the dairy group based on the new MyPryamid guidelines state that 3 cups are recommended everyday. ${ }^{10}$ This is very similar when compared to the 1996 Food Guide Pyramid in which 2-3 servings are recommended with the serving size consisting of 1 cup of milk or yogurt. ${ }^{17}$ However, only $17.54 \%$ of the participants $(n=10)$, are getting the recommended servings of dairy per day. Calcium is an important source for growing strong, healthy bones. Not getting proper amounts of calcium in the diet can pose a big health risk for adolescent athletes now and in the future.

Athletes are not getting the recommended servings in the fruit and bread and cereal group. Only $28.07 \%$ of participants $(n=16)$, eat the MyPryamid recommended 2 cups of fruit per day. ${ }^{10}$ The serving sizes is similar to the 1996 Food Guide Pyramid of 
2-4 servings per day consisting of 1 medium piece of fruit or $1 / 2$ cup of chopped fruit. ${ }^{17}$ Twenty-six and four tenths percent of participants $(\mathrm{n}=15)$, are consuming the recommended servings of meat or protein. MyPyramid recommends that adolescents consume 5.5 oz of meat and beans daily. ${ }^{10}$ This is similar to the 1996 Food Guide Pyramid's recommendations of 2-3 servings consisting of 2-3 ounces of chicken or beef per day. ${ }^{17}$ Only $12.3 \%$ of the football players ( $\left.n=7\right)$, are getting $6-11$ servings of bread/cereal that is recommended by the 1996 Food Guide Pyramid. ${ }^{17}$ MyPryamid recommends similar amounts of 6 ounces of grains per day, but emphasizes the importance of whole grains. ${ }^{10}$ The one thing to keep in mind when analyzing the results to the diet recall is that the diet recall questioned how many times in the last seven days these foods/drinks were consumed. This questionnaire did not ask about serving sizes. With the portion sizes in today's world, these answers may change. Because of the larger serving sizes that are eaten today, many of these athletes may be consuming the recommended amount of servings or even more. This needs to be kept in mind when determining if the athletes are making appropriate food choices.

There were encouraging results from this study. Question number 12 asked how many times the participants had eaten fast food in the last week. The results indicated that the majority of the participants $(71.9 \%, \mathrm{n}=41)$ ate fast food only once or not at all in the past seven days. These numbers are surprising considering the prevalence of fast food in today's world. Eating fast food only one time in a week is not a poor choice when considering that some fast food choices may actually be healthy. In this study, less junk food was consumed than anticipated. Only $33.3 \%(n=19)$ of the participants responded that they ate junk food once or twice a day. This seems low when thinking of 
the large amounts of food that can be considered junk food. One study indicated that $77.5 \%$ of participants ate junk food daily and the majority consumed junk food several times a day. ${ }^{7}$ Besides consuming fast food, athletes may also increase their intake of soda. Question number 13 asked how much soda that the participants drank in the last seven days. The results indicated that the participants are not drinking soda in excess. Fifty-seven and nine tenths $(\mathrm{n}=33)$ of the participants drank soda only one time in the last week or not at all. These numbers seem low compared to one study that claimed that $79.4 \%$ of adolescents consume soft-drinks daily. ${ }^{4} \quad$ That study also blamed soda consumption for the obesity problem among children and adolescents in today's society.

High school football is a popular sport that involves high-intensity activity, training, and competition. Because of these high demands placed on them, their nutritional needs will vary considerably depending on their level of participation. ${ }^{16}$ The American Dietetic Association (ADA) recommends that adolescent athletes in organized sports engage in healthful and balanced nutrition practices that promote optimal growth and performance. ${ }^{1}$ A poor diet can hinder performance in any sport especially high intensity sports such as football. High school football players lack the application of any nutrition knowledge that they may have, setting them up for injury or illness. ${ }^{2}$ The football athletes in this study are consuming the recommended amounts of meats and protein and are drinking enough water, but they are under the recommended amounts of dairy, fruit, vegetables, and grains. The results from this study are somewhat similar to a study by Speck $^{8}$ who completed a study using the Eating Habits Questionnaire (EHQ) with 446 middle school students. Results from their study concluded that adolescents consumed higher than recommended daily servings for fats, sweets, and meats and lower 
than recommended servings of vegetables and breads. With more nutritional education proper food choices can be made by adolescent athletes.

The diet recall that was given to the athletes may not have been the most accurate of assessments to find the exact food choices being made by the participants because it asked how many times a certain food/drink was consumed instead of questioning the servings. A diet recall may not be representative of usual intake and relies on memory, which may alter the actual food intakes. ${ }^{18}$ A food diary may have been more accurate, but participants compliance rates might have been lower. To help account for any mistakes from memory, the one problem that appears to be consistent with diet recall is that children and adolescents cannot remember the foods that they have eaten. Greger ${ }^{19}$ conducted a study on 24 hour diet recalls and tested 32 adolescent girls in a 30 day metabolic study. Their study reported different results and indicated that the participants would miss food on a recall that they ate, rather than add wrong items or misidentify foods. Although diet recalls were a valid base of estimating the dietary intake, the older participants were unable to recall their food intake with enough accuracy so that their intakes were calculated within a range of two-thirds to four-thirds of their actual intake. ${ }^{20}$ Weber and colleagues ${ }^{21}$ have found this to not be the case. Using 80 third grade students in their study, they found that $75 \%$ of the children were able to correctly recall the foods they were observed consuming, and correctly recalled $83 \%$ of foods by food group.

The diet recalls are adequate tools to assess the needs of nutrition knowledge and dietary habits of athletes and adolescents alike. However, for this study population it is not known whether a seven day diet recall was accurate. Other studies have indicated that a seven day diet recall provides more information than a 24 hour recall. Diets vary 
from day to day and a longer period of time will help to get an accurate picture of what the participants had consumed. A 7-day diet recall can result in a more accurate picture of what the participant is consuming on a regular basis. Because of the longer time period, the participants can recall regular food choices, compared to that of only one 24hour period where their eating may have been altered on that particular day. ${ }^{21} \mathrm{~A}$ food diary may be more of an accurate tool to use when evaluating food choices of a population. This type of diet recall provides information on both qualitative and quantitative aspects of a usual diet. ${ }^{8}$ A food diary captures day-to-day and seasonal variation of food choices. It could require more of a commitment from the participants and may require help from parents if given to children or adolescents. Perhaps the best way to record actual food choices is to use a weighted diet record. This includes the participants actually weighing each food item on a scale and recording the weights of all foods and drinks consumed. ${ }^{9}$ However, this type of recall includes a high respondent burden and is expensive and time consuming to administer. The diet recall needs to be selected to accommodate the participants, information being evaluated, and the resources available to the researcher.

\section{CONCULSION}

High School football players are not knowledgeable about nutrition. Even though they learn about the Food Guide Pyramid and the servings and serving sizes in health class in ninth grade, they are not retaining this knowledge or making good food choices based on it. Approximately $56.14 \%$ of the participants scored a passing grade ( $70 \%$ or better) on the nutritional knowledge questionnaire. The results of the five groupings indicated that the participants are knowledgeable about diet and hydration, but not about 
carbohydrates/proteins, fruits/vegetables, and vitamins/minerals. This indicates a need to incorporate nutrition education throughout the curriculum. The diet recall indicates that the high school football players are eating fast foods, junk food, and soda sparingly. They are also consuming the recommended amounts of meats and protein and are drinking enough water, but they are under the recommended amounts of dairy, fruit, vegetables, and grains. With more nutritional education proper food choices can be made by adolescent athletes.

Because of their activity level, football players need to be more aware of their food intake. The food that is eaten affects their athletic performance, which means that they have to have proper nutrients and energy to perform at optimal levels. The nutritional knowledge that they do have is not being applied to their food choices everyday. Further education needs to be completed to help this ever-growing problem and improve adolescents' nutritional knowledge to make proper food choices. 


\section{REFERENCES}

1. Loud K, Field A, Micheli L. Primary care of the elite-emulating adolescent male athlete. Adolesc Med. 2003;14(3):647-661.

2. Hickson JF, Duke MA, Risser WL, et al. Nutritional intake from food sources of high school football athletes. J Am Diet Assoc. 1987;87(12):1656-1659.

3. Mitchell C. Nutrition knowledge of high school athletes. West Virginia University School of Physical Education Thesis. 2004;3-14.

4. Werblow JA, Fox HM, Henneman A. Nutritional knowledge, attitudes, and food patterns of women athletes. J Am Diet Assoc. 1978;73(3):242-245.

5. Pirouznia M. The association between nutrition knowledge and eating behavior in male and female adolescents in the US. Int J Food Sci Nutr. 2001;52(2):127-132.

6. Schmalz K. Nutritional beliefs and practices of adolescent athletes. J Sch Nurs. 1993;9(2):18-22.

7. Frary CD, Johnson Rk, Wang MQ. Children and adolescents' choices of food and beverages high in added sugars are associated with intakes of key nutrients and food groups. J Adolesc Health. 2001;28(1):16-25.

8. Speck BJ, Bradley CB, Harrell JS, Belyea MJ. A food frequency questionnaire for youth: psychometric analysis and summary of eating habits in adolescents. J Adolesc Health. 2001;28(1):16-25.

9. Harnack L, Walters SA, Jacobs DR Jr. Dietary intake and food sources of whole grains among US children and adolescents: data from the 1994-1996 Continuing Survey of Food Intakes by Individuals. J Am Diet Assoc. 2003;103(8):1015-1019.

10. US Department of Health and Human Services, US Department of Agriculture. Food Guide Pyramid. www.mypyramid.gov. Accessed on 7-505 .

11. Centers for Disease Control and Prevention. 2005 Youth Risk Behavior Survey. www.cdc.gov/healthyyouth/yrbs/ Accessed August 25,2005.

12. Buergel NS, Bergman EA. Students consuming sack lunches devote more time to eating than those consuming school lunches. J Am Diet Assoc. 2002;102(9):1283-1286. 
13. WV Board of Education. Standards for school nutrition. Title 126. http://wvde.state.ev.us/policies/p4321.1. Accessed May 18, 2005.

14. Dwyer JT, Evans M, Stone EJ, Feldman HA, Lyte L, Hoelscher D, et al. Adolescents' eating patterns influence their nutrient intakes. J Am Diet Assoc. 2001;101(7):798-802.

15. Jansen GR, Shigetomi CT, Mackin SD, Iyer PA, Dailey BJ, Harper JM. Alternate lunch patterns in high school. IV. Nutritive value. $J$ Am Diet Assoc. 1980;77(5):546-551.

16. Jonnalagadda SS, Rosenbloom CA, Skinner R. Dietary practices, attitudes, and physiological status of collegiate freshman football players. J Strength Cond Res. 2001;15(4):507-513.

17. USDA, Center for Nutrition Policy and Promotion. Food Guide Pyramid. Home and Garden Bulletin Number 252, from October 1996. http://www.usda.gov/cnpp/pyrabklt.pdf. Accessed November 5, 2005.

18. Livingstone MB, Robson PJ. Measurement of dietary intake in children. Proc Nutr Soc. 2000;59(2):279-293.

19. Greger JL, Etnyre GM. Validity of 24-hour diet recalls by adolescent females. Am J Public Health. 1978;68(1):70-72.

20. Rockett HR, Colditz GA. Assessing diets of children and adolescents. Am J Clin Nutr. 1997;1116-1122.

21. Weber JL, Lyte L, Gittelsohn J. et al. Validity of self-reported dietary intake at school meals by American Indian children: the Pathways Study. J Am Diet Assoc. 2004;104(5):746-752.

22. Vereecken CA, Covents M, Matthys C, Maes L. Young adolescents' nutrition assessment on computer (YANA-C). Euro J Clin Nutr. 2005;59:658-667. 
APPENDICES 


\section{APPENDIX A}

\section{THE PROBLEM}

\section{Research Question}

Nutrition is a vital component in regard to the health of the athlete. However, more emphasis in the sport's world is placed on hydration and dietary supplements rather than the actual diet of the athletes. ${ }^{3}$ If all of these factors are combined in the proper proportions, results for success in athletics are evident. The American Dietetic Association (ADA) recommends that adolescent athletes in organized sports engage in healthful and balanced nutrition practices that promote optimal growth and performance. ${ }^{1}$ A poor diet can hinder performance in any sport especially high intensity sports such as football. High school football players lack the application of any nutrition knowledge that they may have, predisposing them to injury or illness. ${ }^{2}$ Therefore, high school football players need to become better educated on proper nutrition and then to apply this knowledge into their own lifestyles. There are many different factors that may have immeasurable influences between and within each athlete. Factors that could influence an adolescent's food choices are: nutrition knowledge, physiological needs, body image, food preferences, parental practices, peers, media, social norms, fast foods, and personal experiences. $^{5}$

In high school athletics, nutrition is rarely discussed as an important tool to use to improve performance. Adolescent athletes lack the appropriate knowledge on proper diet. The information they have at the high school level usually comes from parents, coaches, or advertisements. This information can be very misleading due to the lack of knowledge of the sources themselves. High school health class can be another source of 
nutrition information. However, many of these health classes may not cover nutrition and are only taught in the freshman year. West Virginia Department of Education requires that all health classes are taken during freshman year and cover nutrition. ${ }^{13}$

There are thousands of high school football players across the country and the numbers are growing every year. The dangers from an improper diet can be catastrophic, as the main diet for adolescents usually consist of fast food, pizza, potato chips, and candy. ${ }^{5,13}$ Most adolescents do not eat breakfast and eat a lunch consisting of mostly junk food. Many athletes report that they sleep through breakfast or do not have time to eat. ${ }^{2}$ This may be all they consume before an after school practice. Thus, the proper nutrients that are necessary for any athletic endeavor can be tremendously lacking. This can hamper their performance at practice each day, which can lead to injury or illness.

The high intensity of high school football, especially during summer camp when there can be 2 practices everyday, increases the need for each athlete to become knowledgeable about proper nutrition and apply that knowledge. Proper nutrients need to be consumed to get through practice everyday. Having better knowledge on the proper foods to consume to enhance athletic performance will help the athletes make better food choices. ${ }^{16}$ Most high school athletes may know the right foods to eat and what foods to avoid in excess. However, the actual application of this knowledge is lacking. The research question is how knowledgeable are high school football players about proper nutrition and are they applying this knowledge into their everyday life?

Experimental Hypotheses

1. Based on the responses from the nutrition knowledge questionnaire, high school football players will be knowledgeable ( $70 \%$ or better) about proper nutrition. 
2. Based on the diet recall responses, high school football players do not apply their nutrition knowledge in everyday life.

3. There will be a significant difference for total score on the nutrition knowledge questionnaire between the year in school for high school football players.

4. There will be a significant difference for the five groupings on the nutrition knowledge questionnaire between year in school for high school football players.

5. There will be a significant difference between the responses on the diet recall and year in school for high school football players.

\section{Assumptions}

1. The nutrition knowledge questionnaire is an appropriate tool to test nutrition knowledge.

2. The diet recall will be an appropriate tool to assess application of nutritional knowledge.

3. The diet recall will be filled out according to the directions.

4. The athletes will complete the nutritional knowledge questionnaire and diet recall to the best of their ability.

5. The athletes will be honest when answering the nutrition knowledge questionnaire and the diet recall.

\section{Delimitations}

1. This study used participants from only one high school football team at a small high school in north central West Virginia. This study does not give an accurate picture of other high schools or other athletes on other sports teams.

2. The small sample size in the study may not be generalized to the entire population.

\section{Operational Definitions}

1. Amino acids - the building block of protein. ${ }^{23}$

2. Caffeine - a natural stimulant found in foods like chocolate, coffee, tea, and soda. ${ }^{23}$

3. Calorie - unit of measurement for energy of food. ${ }^{13}$

4. Carbohydrates - are a source of calories from sugars and starches that fuel your muscles and brain. ${ }^{13,23}$ 
5. Dehydration - reductions of body water below normal levels. ${ }^{13}$

6. Diet - the foods and beverages a person eats and drinks in a day or a week. ${ }^{23}$

7. Diet Recall - form used to record information regarding the foods that were consumed in the last few days. ${ }^{13,23}$

8. Electrolytes - substances are found in the cells of the body and the movement of electrolytes initiates a variety of actions. Examples are sodium and potassium. ${ }^{10}$

9. Essential nutrients - nutrients a person must consume from food because the body cannot make them to meet the needs of the body. ${ }^{10,23}$

10. Fats - a source of stored energy that is burned mostly during low-level activity and long-term activity. ${ }^{23}$

11. Food Guide Pyramid - a group approach to healthful nutrition containing five food groups consisting of grains, vegetables, fruits, milk, and meat and beans. ${ }^{10}$

12. Metabolism - the sum total of all the chemical reactions that go on in daily living cells. ${ }^{10,13,23}$

13. Mineral - elements obtained from foods that combine in many ways to form structures of the body and regulate body processes. ${ }^{10,23}$

14. Nutrients - chemical substances obtained from food and used in the body to provide energy, growth, maintenance, and tissue repair. ${ }^{10,13,23}$

15. Nutrition - the science of foods, nutrients, and other substances contained in food, and their actions within the body. ${ }^{23}$

16. Proteins - made up of amino acids that is essential for building and repairing muscles, red blood cells, hair and other tissues. ${ }^{23}$

17. Recommended Daily Allowance (RDA) - the average daily amount of a nutrient considered adequate to meet the known nutrient needs of most healthy people. ${ }^{23}$

18. Saturated Fat - a fat, most often of animal origin, that is solid at room temperature and whose fatty acid chains cannot incorporate additional hydrogen atoms. ${ }^{13}$

19. Serving Size - amount of food based on what people typically eat, and are listed on all food containers, used to determine the amount of calories, vitamins, etc. in the amount of food equal to one serving size. Serving sizes are provided in familiar 
units, such as cups or pieces, followed by the metric amount, e.g., the number of grams. ${ }^{10,13,23}$

20. Trans Fat - a fat containing trans-fatty acids produced by the partial hydrogenation of vegetable oils and present in hardened vegetable oils, most margarines, commercial baked foods, and many fried foods. ${ }^{13}$

21. Vitamins - metabolic catalysts that regulate biochemical reaction within the body. ${ }^{13,23}$

22. Water - an essential substance made of hydrogen, and oxygen that makes up to 60$75 \%$ of the body. ${ }^{10,13,23}$

\section{Limitations}

1. Athletes may not complete the entire nutritional knowledge test or they may not be honest in their answers.

2. The diet recall may not be filled out as specified in the directions.

3. The diet recall may not accurately illustrate a normal diet.

\section{Significance of the Study}

Poor diets can hinder athletic performance especially in high school athletes that are still maturing and growing. This study will show the need for more on-going knowledge of nutrition for all high school students, especially those participating in sports based on the nutritional knowledge questionnaire scores. One health class throughout high school may not be enough. With continual nutrition education from classes throughout high school, the athletes may become more knowledgeable on the subject. Recent research suggests that the adolescent athlete is neither aware nor prepared for the dual demands of sound nutritional practices in general and those demanded by his or her chosen sport activities. This study can help show the need to prepare the athletes for these demands. 
The study will also show the need for improvement of high school football players applying their nutritional knowledge to their diet. Diet recalls are adequate tools to assess the needs of nutritional knowledge and dietary habits of athletes and adolescents alike. The diet recall will assess the nutritional needs of the high school football players. It will show the positive aspects of their diet and the aspects that need to be changed. The diet recall will indicate that the eating habits among high school football players need vast improvement. These improvements can then be recommended to the athletes and coaches, to help improve on healthful eating habits by showing what eating habits are in place and the ones that need to be put into action.

Many improvements can be made in regard to the diets of all high school football players to improve performance and prevent illness and injury. This study will help provide the status of current eating habits and ways to improve these habits for a healthy overall athlete. By distributing the results to the athletes and coaches, they will know where they stand as of now and what changes can be made to enhance their athletic skills through a proper diet. When the diet of the high school athlete improves, the groundwork for healthy habits for life will be established. 


\section{APPENDIX B \\ LITERATURE REVIEW}

Introduction

Nutrition plays a vital role in the health of athletes. Lack of nutritional knowledge can lead to poor eating habits which can then affect the performance of the athlete. The American Dietetic Association (ADA) recommends that adolescent athletes in organized sports engage in healthful and balanced nutrition practices that promote optimal growth and performance. ${ }^{1}$ However, the average athlete does not consume the adequate nutrients necessary for a well balanced diet. ${ }^{2}$

The diet for the average adolescent is comprised of mostly junk food, with little to no vegetables and fruit. ${ }^{13}$ This type of diet leaves little room for the essential nutrients necessary for sport participation. High school football players lack the application of any nutrition knowledge that they may have, predisposing them to injury or illness. ${ }^{2}$ Therefore, high school football players need to become better educated on proper nutrition and then need to apply this knowledge into their own lifestyles. This literature review will cover basic nutrition, adolescent nutrition, nutritional education, nutritional knowledge studies and diet recall.

Basic Nutrition

The U.S. Department of Agriculture (USDA) has written the 2005 Dietary Guidelines for Americans to be the primary source of dietary health information for policymakers, nutrition educators, and health providers. ${ }^{13}$ These guidelines are based on recommendations put forward by the Dietary Guidelines Advisory Committee, to provide science-based advice to promote healthy living for all Americans. Following these 
guidelines will provide a good base for healthy eating habits. The USDA, Dietitians of Canada, and the American College of Sports Medicine (ACSM) state that physical activity, athletic performance, and recovery from exercise are enhanced by optimal nutrition. ${ }^{13,23,24}$ The basic components of nutrition are carbohydrates, proteins, fats, vitamins and minerals.

Carbohydrates: Carbohydrates provide the main source of energy in the body. They fuel muscles and promote good health. ${ }^{23}$ There are both simple and complex carbohydrates. Simple carbohydrates are categorized into monosaccharides and disaccharides and complex carbohydrates are starches in plant food and stored as glycogen in muscles. ${ }^{23}$ Carbohydrates are broken down in the body and converted into energy via glycolysis. Choosing plenty of whole grain carbohydrates and fiber-rich fruits and vegetables is important when planning meals and in fulfilling the requirements of the recommended $60 \%$ carbohydrates by the USDA. ${ }^{10}$ This will maximize the important nutrients without consuming too many calories. Adolescent athletes need a diet consisting of carbohydrates to ensure energy from the proper sources. Carbohydrates are also important to maintain blood-glucose levels during exercise and to replace muscle glycogen. ${ }^{10}$

Protein: Protein is made up of essential amino acids that are very important in the body for building cells, tissues, and organs. ${ }^{13,23}$ Adolescent athletes need proper amounts of protein for both growth and sports. The USDA recommends about $20-25 \%$ of ones diet to consist of protein. ${ }^{24}$ Contrary to belief, consuming additional amounts of protein does not help build muscle. ${ }^{24}$ Most people obtain the required amount of protein through their regular diet without the need to take extra protein supplements or shakes. Taking in 
extra protein does nothing beneficial for the body, as the excess is excreted. Consuming lean meats, fish and beans are recommended ways of consuming proper amounts of protein without high caloric intake. ${ }^{10}$

Fats: Fats are necessary for a healthy diet. The USDA recommends about 15$20 \%$ of ones diet to come from fat for adolescent athletes. ${ }^{13}$ It is important to consume the right type of fat. A diet high in saturated fats and trans fats lead to high cholesterol and an unhealthy lifestyle. ${ }^{23}$ Fats supply energy and essential fatty acids and serve as a carrier for the absorption of the fat-soluble vitamins A, D, E, and K and carotenoids. ${ }^{13}$ Saturated fats are usually solid or almost solid at room temperature. All animal fats, such as those in meat, poultry, and dairy products are saturated, as well as processed and fast foods. ${ }^{13}$ Trans fats also called hydrogenated fats, are fats that are created when oils are partially hydrogenated. ${ }^{23}$ The process of hydrogenation changes the chemical structure of unsaturated fats by adding hydrogen atoms to make the fats more saturated.

Hydrogenation is what turns liquid oil into stick margarine or shortening. ${ }^{13}$ This process is used to increase product stability and shelf life. Many people over-consume the amount of calories in their diet due to soft-drinks and fast food. ${ }^{25}$

Vitamins/Minerals: Vitamins are metabolic catalysts that regulate biochemical reactions within the body. ${ }^{23}$ The body does not produce vitamins and must consume the recommended requirement of vitamins through a proper diet. Vitamins A, B, C, D, E, and $\mathrm{K}$ are important nutrients to consume following the recommended amounts by eating a proper diet. Vitamins can be broken down into fat-soluble (Table B1) and watersoluble vitamins (Table B2). The water-soluble vitamins, excluding vitamin C, are popularly termed the B-complex vitamins. There are eight of them, namely; B1 
(thiamine), B2 (riboflavin), B3 (niacin, nicotinic acid), B6 (pyridoxine), B12, folic acid, pantothenic acid, and biotin. ${ }^{23}$ The water-soluble vitamins are absorbed in the intestine, pass directly to the blood, and are carried to the tissues in which they will be utilized. Unlike water-soluble vitamins that need regular replacement in the body, fat-soluble vitamins are stored in the liver and fatty tissues, and are eliminated much more slowly than water-soluble vitamins. ${ }^{23}$ Vitamins A,D,E, and $\mathrm{K}$ are fat-soluble vitamins. Vitamin supplements are usually unnecessary for adolescent athletes unless they have a certain deficiency. ${ }^{26}$ Minerals are present in all living cells and occur frequently in nature in the soil and water which is transferred into plants and then into animals. ${ }^{23}$ There are many important minerals that are necessary to consume everyday such as iron, calcium, zinc, and many more. Each of these minerals has a unique and important role in the body. Like vitamins, mineral supplements are usually unnecessary in the adolescent athlete unless a deficiency is present. ${ }^{26}$ The information about the major minerals are listed in Table B3.

Table B1. Fat-Soluble Vitamins. ${ }^{24}$

\begin{tabular}{|c|c|c|c|c|c|}
\hline Vitamin & RDA & & Function & Major Sources & Deficiency Symptoms \\
\hline Vitamin A & $\begin{array}{l}800 \mathrm{ug}(\mathrm{f}) \\
\mathrm{ug} .(\mathrm{m})\end{array}$ & 1,000 & $\begin{array}{l}\text { Helps keep skin and } \\
\text { lining of nose, mouth, } \\
\text { throat healthy. }\end{array}$ & $\begin{array}{l}\text { Liver, whole milk, cheese, } \\
\text { carrots, green leafy } \\
\text { vegetables, sweet potatoes. }\end{array}$ & $\begin{array}{l}\text { Night blindness, } \\
\text { intestinal infections, } \\
\text { impaired growth }\end{array}$ \\
\hline Vitamin D & $5 \mathrm{ug}$ & & $\begin{array}{l}\text { Helps body use calcium } \\
\text { and phosphorus to build } \\
\text { and maintain strong } \\
\text { bones and teeth. }\end{array}$ & $\begin{array}{l}\text { Fortified milk, exposure to } \\
\text { sunlight, fatty fish, eggs, } \\
\text { liver, butter. }\end{array}$ & $\begin{array}{l}\text { Rickets in children and } \\
\text { osteomalacia in adults } \\
\text { (rare) }\end{array}$ \\
\hline Vitamin E & $\begin{array}{l}8 \mathrm{mg}(\mathrm{f}) \\
10 \mathrm{mg}(\mathrm{m})\end{array}$ & & $\begin{array}{l}\text { Helps keep red blood } \\
\text { cells intact. }\end{array}$ & Vegetable oils, margarine. & $\begin{array}{l}\text { Anemia, disruption of } \\
\text { red blood cell } \\
\text { membrane (very rare) }\end{array}$ \\
\hline Vitamin K & $\begin{array}{l}65 \mathrm{mg}(\mathrm{f}) \\
80 \mathrm{mg}(\mathrm{m})\end{array}$ & & $\begin{array}{l}\text { Involved in synthesis of } \\
\text { proteins required for } \\
\text { blood clotting. }\end{array}$ & $\begin{array}{l}\text { Green leafy vegetables, } \\
\text { dairy products, meats, eggs, } \\
\text { cereals, fruits. }\end{array}$ & $\begin{array}{l}\text { Increase bleeding and } \\
\text { hemorrhage }\end{array}$ \\
\hline
\end{tabular}


Table B2. Water-Soluble Vitamins. ${ }^{24}$

\begin{tabular}{|c|c|c|c|c|}
\hline Vitamin & RDA & Function & Major Sources & Deficiency Symptoms \\
\hline $\begin{array}{l}\text { Vitamin } \mathrm{B}_{1} \\
\text { (Thiamin) }\end{array}$ & $\begin{array}{l}1.2 \mathrm{mg}(\mathrm{f}) \\
1.5 \mathrm{mg} \mathrm{(m)}\end{array}$ & $\begin{array}{l}\text { Helps body cells obtain } \\
\text { energy from food. }\end{array}$ & $\begin{array}{l}\text { Pork, liver, wheat germ, } \\
\text { whole grain cereals and } \\
\text { breads. }\end{array}$ & $\begin{array}{l}\text { Poor appetite, apathy, } \\
\text { depression, pain in calf } \\
\text { muscles }\end{array}$ \\
\hline $\begin{array}{l}\text { Vitamin } \mathrm{B}_{2} \\
\text { (Riboflavin) }\end{array}$ & $\begin{array}{l}1.3 \mathrm{mg}(\mathrm{f}) \\
1.7 \mathrm{mg}(\mathrm{m})\end{array}$ & $\begin{array}{l}\text { Aids in utilization of } \\
\text { protein, fat, and carbs } \\
\text { for energy. }\end{array}$ & $\begin{array}{l}\text { Milk, organ meats, and } \\
\text { enriched breads and cereals. }\end{array}$ & $\begin{array}{l}\text { Dermatitis, sores on } \\
\text { tongue, cornea damage }\end{array}$ \\
\hline $\begin{array}{l}\text { Vitamin } B_{3} \\
\text { (Niacin) }\end{array}$ & $\begin{array}{l}15 \mathrm{mg}(\mathrm{f}) \\
17-20 \mathrm{mg}(\mathrm{m})\end{array}$ & $\begin{array}{l}\text { Helps synthesize fat, } \\
\text { blocks release of fatty } \\
\text { acid, needed for healthy } \\
\text { skin }\end{array}$ & $\begin{array}{l}\text { Lean meats, poultry, beans, } \\
\text { whole-grains }\end{array}$ & $\begin{array}{l}\text { Loss of appetite, } \\
\text { weakness, skin lesions }\end{array}$ \\
\hline Vitamin $\mathrm{B}_{6}$ & $\begin{array}{l}1.4-1.5 \mathrm{mg}(\mathrm{f}) \\
1.7-2 \mathrm{mg} .(\mathrm{m})\end{array}$ & $\begin{array}{l}\text { Functions as a } \\
\text { coenzyme in protein } \\
\text { metabolism, necessary } \\
\text { for formation of } \\
\text { hemoglobin }\end{array}$ & $\begin{array}{l}\text { Protein foods, liver meats, } \\
\text { fish, poultry, legumes, green } \\
\text { leafy vegetables }\end{array}$ & $\begin{array}{l}\text { Nervous irritability, } \\
\text { convulsions, dermatitis, } \\
\text { anemia }\end{array}$ \\
\hline Vitamin $B_{12}$ & $2 \mathrm{ug}$ & $\begin{array}{l}\text { Needed to build healthy } \\
\text { red blood cells and } \\
\text { normal growth in } \\
\text { children. }\end{array}$ & $\begin{array}{l}\text { Found only in foods of animal } \\
\text { origin, like liver, meat, milk, } \\
\text { eggs, cheese. }\end{array}$ & $\begin{array}{l}\text { Pernicious anemia, } \\
\text { nerve damage resulting } \\
\text { in paralysis }\end{array}$ \\
\hline Vitamin C & $\begin{array}{l}75(\mathrm{f}) \\
90(\mathrm{~m})\end{array}$ & $\begin{array}{l}\text { Helps hold body cells } \\
\text { together and strengthens } \\
\text { walls of blood vessels. }\end{array}$ & $\begin{array}{l}\text { Citrus fruits, green peppers, } \\
\text { tomatoes, strawberries, } \\
\text { cabbage, broccoli. }\end{array}$ & $\begin{array}{l}\text { Weakness, rough skin, } \\
\text { bleeding gums, scurvy }\end{array}$ \\
\hline
\end{tabular}

Legend: $\mathrm{F}=$ Female, $\mathrm{M}=$ Male

Table B3. Major Minerals. ${ }^{24}$

\begin{tabular}{|c|c|c|c|c|}
\hline Mineral & RDA & Function & Major Sources & Deficiency Symptoms \\
\hline Calcium $(\mathrm{Ca})$ & $800 \mathrm{mg}$ & $\begin{array}{l}\text { Assists in clotting of } \\
\text { blood and building of } \\
\text { bones and teeth. }\end{array}$ & $\begin{array}{l}\text { All forms of milk, cheese, } \\
\text { ice cream. }\end{array}$ & $\begin{array}{l}\text { Osteoporosis, rickets, } \\
\text { impaired muscle } \\
\text { contractions, muscle } \\
\text { cramps. }\end{array}$ \\
\hline Phosphorus (P) & $800 \mathrm{mg}$ & $\begin{array}{l}\text { With calcium, helps } \\
\text { build bones and teeth, } \\
\text { aids in release of energy } \\
\text { from carbs, fats, } \\
\text { proteins. }\end{array}$ & $\begin{array}{l}\text { Meat, poultry, fish, eggs, } \\
\text { dried peas, and beans. }\end{array}$ & Muscular weakness (rare). \\
\hline Magnesium $(\mathrm{Mg})$ & $\begin{array}{l}280 \mathrm{mg}(\mathrm{f}) \\
350 \mathrm{mg}(\mathrm{m})\end{array}$ & $\begin{array}{l}\text { Needed for contraction } \\
\text { of nerves and muscles } \\
\text { and for normal } \\
\text { metabolism of } \\
\text { potassium and calcium. }\end{array}$ & $\begin{array}{l}\text { Nuts, whole grains, dried } \\
\text { peas and beans, milk, } \\
\text { green leafy vegetables. }\end{array}$ & $\begin{array}{l}\text { Muscle weakness, apathy, } \\
\text { muscle twitching, muscle } \\
\text { cramps (rare). }\end{array}$ \\
\hline Iron $(\mathrm{Fe})$ & $\begin{array}{l}15 \mathrm{mg}(\mathrm{f}) \\
10 \mathrm{mg}(\mathrm{m})\end{array}$ & $\begin{array}{l}\text { Makes hemoglobin and } \\
\text { transports oxygen to and } \\
\text { from cells. }\end{array}$ & $\begin{array}{l}\text { Organ meats, oysters, lean } \\
\text { meats, eggs, green leafy } \\
\text { vegetables, dried peas and } \\
\text { beans, breads and cereals. }\end{array}$ & $\begin{array}{l}\text { Fatigue, anemia, impaired } \\
\text { temperature regulation. }\end{array}$ \\
\hline Selenium (Se) & $\begin{array}{l}55 \mathrm{mg}(\mathrm{f}) \\
70 \mathrm{mg}(\mathrm{m})\end{array}$ & $\begin{array}{l}\text { With Vitamin } \mathrm{E} \text {, helps } \\
\text { protect cells from } \\
\text { oxidative damage. }\end{array}$ & $\begin{array}{l}\text { Seafood, kidney, liver, } \\
\text { meat, cereals. }\end{array}$ & $\begin{array}{l}\text { Cardiac muscle damage } \\
\text { (rare). }\end{array}$ \\
\hline Iodine & 150 ug & $\begin{array}{l}\text { Promotes proper } \\
\text { functioning of thyroid } \\
\text { gland. }\end{array}$ & Seafood, iodized salt. & $\begin{array}{l}\text { Muscle cramps, goiter, } \\
\text { protruding eyes. }\end{array}$ \\
\hline Sodium $(\mathrm{Na})$ & $500 \mathrm{mg}$ & $\begin{array}{l}\text { Nerve impulse } \\
\text { conduction, acid-base } \\
\text { balance, blood volume }\end{array}$ & Salt, processed foods. & $\begin{array}{l}\text { Hypoatremia, muscle } \\
\text { cramps, nausea, vomiting, } \\
\text { dizziness, shock, coma. }\end{array}$ \\
\hline
\end{tabular}




\begin{tabular}{lllll} 
Chloride $(\mathrm{Cl})$ & $750 \mathrm{mg}$ & $\begin{array}{l}\text { Nerve conduction, } \\
\text { hydrochloric acid } \\
\text { formation in stomach. }\end{array}$ & $\begin{array}{l}\text { Cured meats, processed } \\
\text { cheese, salt. }\end{array}$ & $\begin{array}{l}\text { Loss of hydrochloric acid, } \\
\text { convulsions, excess } \\
\text { vomiting (rare). }\end{array}$ \\
Potassium $(\mathrm{K})$ & $2,000 \mathrm{mg}$ & $\begin{array}{l}\text { Same function as } \\
\text { sodium but intracellular, } \\
\text { glucose transport into } \\
\text { cell. }\end{array}$ & $\begin{array}{l}\text { Meats, milk, fruits, } \\
\text { vegetables, whole-grains. }\end{array}$ & $\begin{array}{l}\text { Hypokalemia, loss of } \\
\text { appetite, muscle cramps, } \\
\text { irregular heartbeat. }\end{array}$ \\
\hline
\end{tabular}

Legend: $F=$ Female, $M=$ Male

Water: Water is composed of hydrogen and oxygen and is an essential nutrient for the body. Water stabilizes body temperature, carries nutrients to and waste away from cells, and is needed for cells to function. ${ }^{23}$ Water does not provide energy. Athletes need to keep properly hydrated to perform to the best of their ability. Athletes should drink large quantities of water before, during and after exercise to stay properly hydrated. The recommended amounts for athletes to drink is 14-22 ounces of water at least 2 hours prior to exercise, 6-12 ounces of water every 15 to 20 minutes during exercise, and 24 ounces of water for every pound lost during exercise. ${ }^{13}$ This can help prevent dehydration and any heat illness.

The Food Guide Pyramid

The Food Guide Pyramid has been the basis of nutrition as to what and how much to eat. It has been taught in schools since 1996, when it was created. Before 2005, the Food Guide Pyramid and the servings appear as it does in Figure B1. The servings were a set number for each of the six food groups; bread and cereal group (6-11 servings), fruit group (2-4 servings), vegetable group (3-5 servings), dairy group (2-3 servings), the meat and poultry group (2-3 servings), and the fat group (use sparingly). ${ }^{17}$ This pyramid is still found in all of the school textbooks and may be the one still taught today in the classroom. Each of the food groups provide most of the nutrients that are necessary for 
the day. The serving sizes for each food group are listed in figure B2. This information is updated in the new Food Guide Pyramid or "MyPyramid".

The Food Guide Pyramid has been changed and edited throughout the years to keep up with the ever changing lifestyles of Americans. The USDA has revamped the Food Guide Pyramid to make it appropriate for 2005 and made it easier for everyone to read and understand. Now there should be no questions on how or what to eat to meet the USDA daily requirements on the Food Guide Pyramid. The new 2005 USDA Food Guide Pyramid is shown in Figure B3 and Figure B4. The new food groups are grains, vegetables, fruits, milk, and meat and beans. This differs slightly from the old Food Guide Pyramid. The recommended servings for each food group also differ depending on one's age, gender, and activity level. The general recommended servings for each group for active adolescents are as follows: 1 ) grains $=6$ ounces a day; 2 ) vegetables $=2$ $1 / 2$ cups every day; 3 ) fruits $=2$ cups every day; 4 ) milk $=3$ cups every day; 5) meats and beans $=5 \frac{1}{2}$ ounces every day. These servings are based on a 2,000 calorie diet and are a base range for everyone. The actual serving sizes have not changed. One slice of bread is still a serving in the grains group, and one piece of fruit is one serving for the fruit group. The new MyPyramid replaces the 1996 Food Guide Pyramid with an easier to understand and guide to follow for healthier living. 
Figure B1. 1996 Food Guide Pyramid. ${ }^{17}$

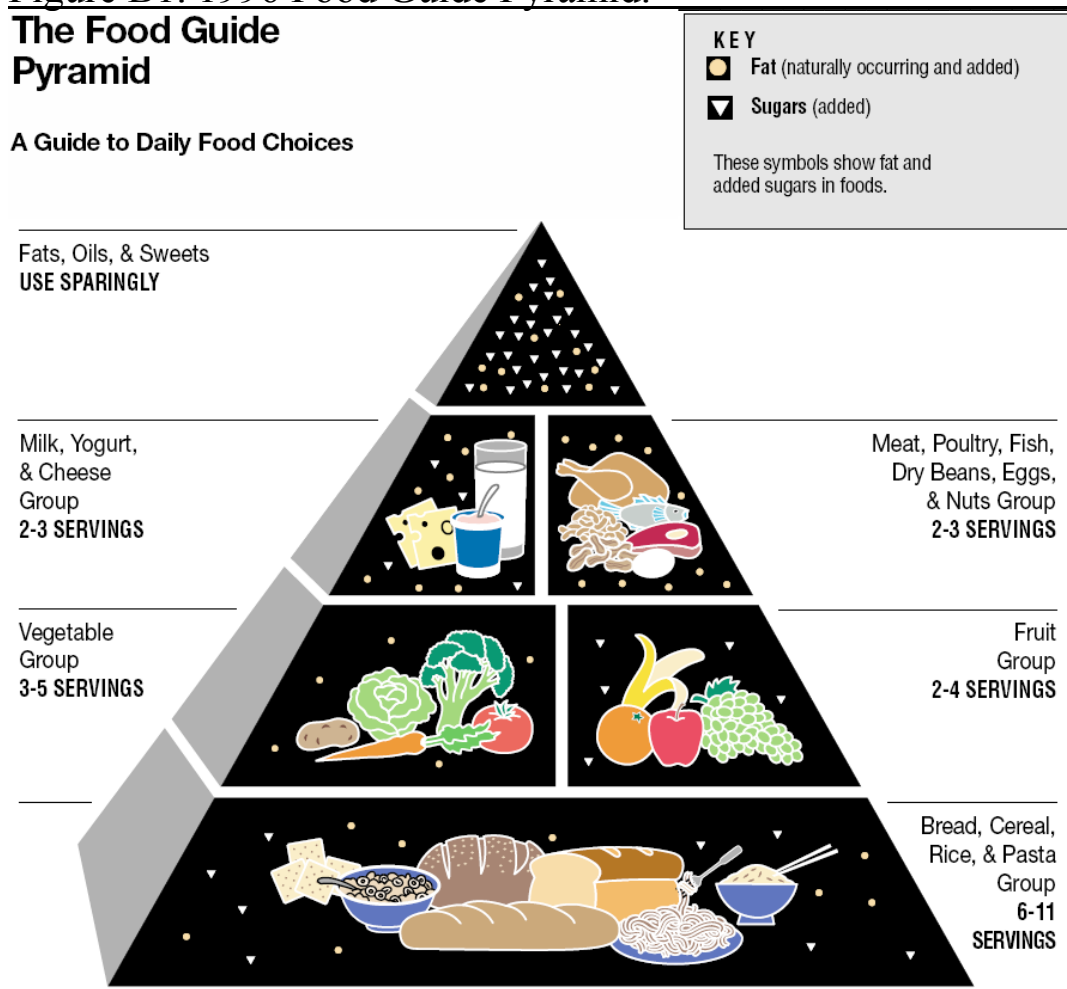

Figure B2. Serving Sizes for the 1996 Food Guide Pyramid. ${ }^{17}$

\section{WHAT COUNTS AS A SERVING?}

\section{Food Groups}

\section{Bread, Cereal, Rice, and Pasta}

\begin{tabular}{c|c|c|}
1 slice of bread & $\begin{array}{c}1 \text { ounce of ready- } \\
\text { to-eat cereal }\end{array}$ & $\begin{array}{c}1 / 2 \text { cup of cooked } \\
\text { cereal, rice, } \\
\text { or pasta }\end{array}$ \\
\hline
\end{tabular}

\section{Vegetable}

\begin{tabular}{c|c|c}
$\begin{array}{c}1 \text { cup of raw leafy } \\
\text { vegetables }\end{array}$ & $\begin{array}{c}1 / 2 \text { cup of other } \\
\text { vegetables, cooked } \\
\text { or chopped raw }\end{array}$ & $\begin{array}{c}3 / 4 \text { cup of } \\
\text { vegetable juice }\end{array}$ \\
&
\end{tabular}

\begin{tabular}{|l|l|l|}
\hline Fruit & \\
\hline $\begin{array}{c}1 \text { medium apple, } \\
\text { banana, orange }\end{array}$ & $\begin{array}{c}1 / 2 \text { cup of } \\
\text { chopped, cooked, } \\
\text { or canned fruit }\end{array}$ & $\begin{array}{c}3 / 4 \text { cup of } \\
\text { fruit juice }\end{array}$ \\
\hline
\end{tabular}

\begin{tabular}{|c|c|c|}
\hline Milk, Yogurt, and Cheese \\
\hline $\begin{array}{c}1 \text { cup of milk or } \\
\text { yogurt }\end{array}$ & $\begin{array}{c}1-1 / 2 \text { ounces of } \\
\text { natural cheese }\end{array}$ & $\begin{array}{c}\text { 2 ounces of } \\
\text { process cheese }\end{array}$ \\
\hline
\end{tabular}

\section{Meat, Poultry, Fish, Dry Beans, Eggs, and Nuts}

2-3 ounces of cooked lean meat, poultry, or fish
$1 / 2$ cup of cooked dry beans or 1 egg counts as 1 ounce of lean meat.

2 tablespoons of peanut butter or $1 / 3$ cup of nuts count as 1 ounce of meat. 
Figure B3. Food Guide Pyramid. ${ }^{10}$

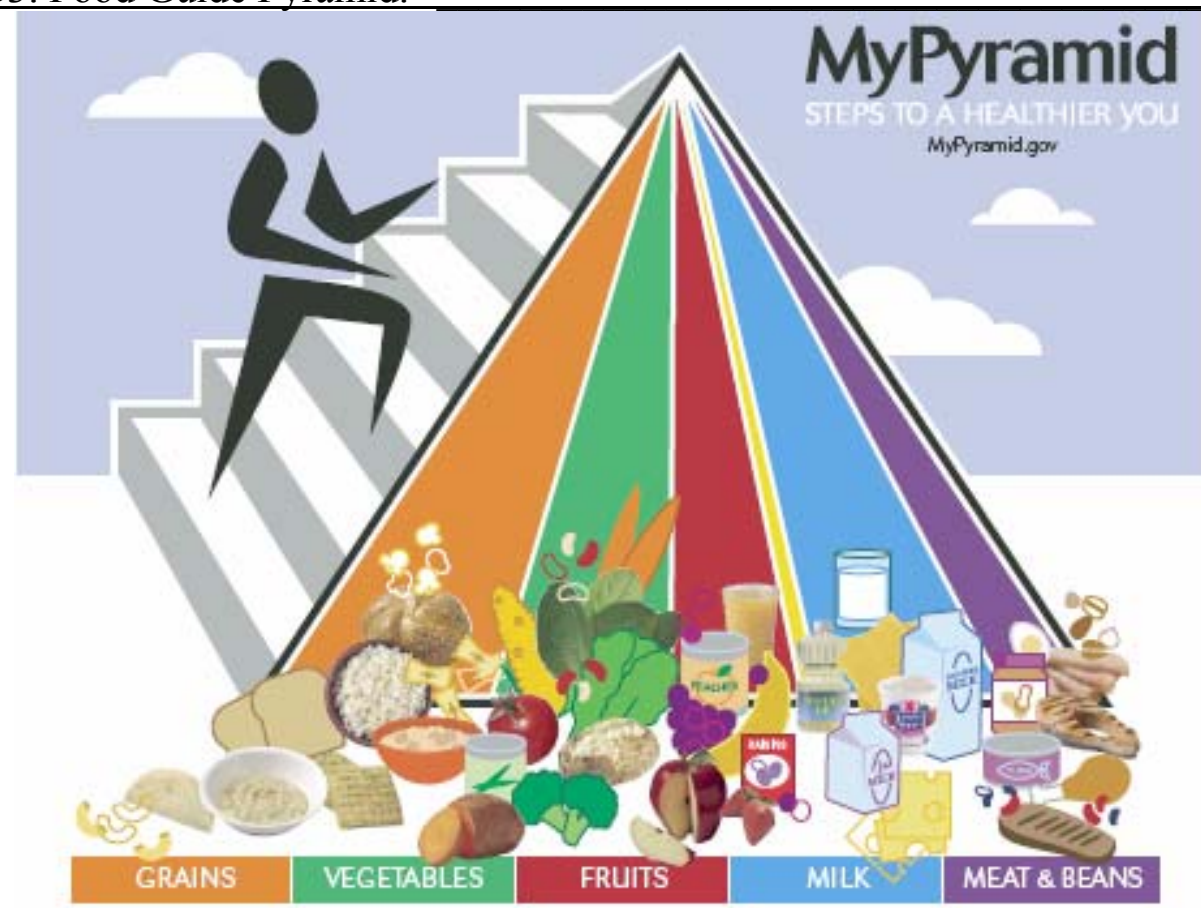

Figure B4. Food Guide Pyramid. ${ }^{10}$

\begin{tabular}{|c|c|c|c|}
\hline $\begin{array}{l}\text { GRAINS } \\
\text { Mese halfycur gere whols }\end{array}$ & $\begin{array}{l}\text { VEGETABLES } \\
\text { Very your voggios }\end{array}$ & $\begin{array}{l}\text { FRUITS } \\
\text { Foars on fiuts }\end{array}$ & $\begin{array}{l}\text { MILK } \\
\text { Cet your ealdumnilch bods }\end{array}$ \\
\hline 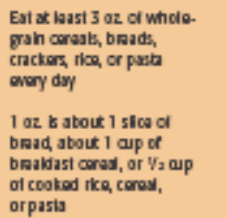 & 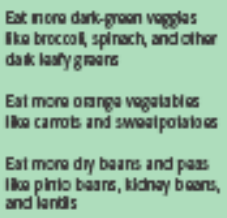 & 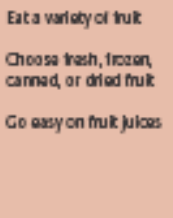 & 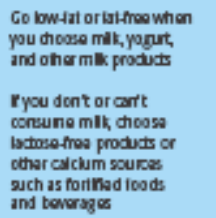 \\
\hline
\end{tabular}

MEAT \& BEANS

Goleen with protan

For a 2,000-ealente dloc, you need the amounts bolow from each bod group. To find the amounts that are night for you, go to Mypyramid gok.

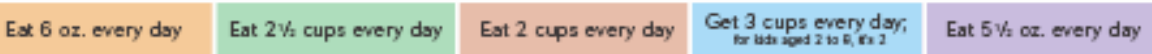

Find your belance between food and physical activity

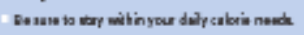

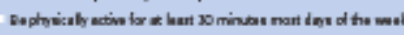

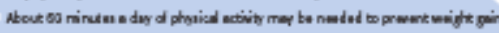

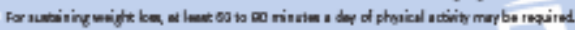

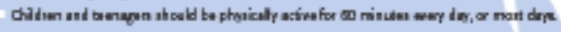

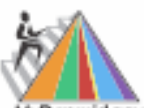

Mbpramidgo
Know the limits on fats, sugars, and salt (sodiumv

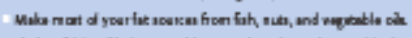

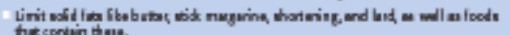

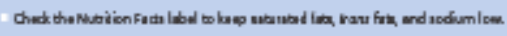

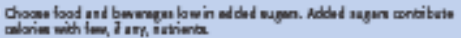




\section{Adolescent Nutrition}

Nutritional habits start early on in life. Adolescence is the time where growth and development is very important, therefore, nutrition during this time is vital in regard to proper health and maturation. ${ }^{9}$ As adolescents go through puberty, bone density and the proportion of body water change and as a result, differ significantly from those of mature adults. ${ }^{24}$ Unhealthy dietary patterns developed during childhood and adolescence may create an increased risk for chronic diseases later in life, such as heart disease, osteoporosis, and certain types of cancer. ${ }^{14,27}$ Adolescents also have more control over their eating habits and more access to food outside the home, experiment more with food choices, deviate more from 3-meal-a-day eating patterns, and are more likely to snack. ${ }^{15}$ Although, having control over their eating habits, most high school athletes may have limited choices in the foods they eat. Most adolescents eat what their parents eat. They eat the foods that are in their homes and what is served to them at school for lunch. ${ }^{28}$ Recent data shows that most U.S. adolescents do not meet dietary recommendations; only one percent ate food from all Food Guide Pyramid groups. ${ }^{27}$

Breakfast consumption has been found to have a significant impact on the nutritional health of adolescents. Breakfast as part of a healthful diet and lifestyle can positively impact children's health and well-being. ${ }^{12}$ Many high school students do not eat breakfast. Fifty-nine percent of high school students indicated that they usually skip breakfast more than three times in a week. ${ }^{12}$ By skipping breakfast, adolescents are already off to a unhealthy start of the day in regard to the essential nutrients missed at breakfast. $^{13}$ 
School lunches are very important when discussing adolescent nutrition.

Everyday there are approximately 27 million children in the U.S. that eat school lunch. ${ }^{29}$ This large number indicates the need for school lunches to be nutritionally sound meals that offer a variety of foods with good nutritional value. The West Virginia Department of Education has developed Standards for School Nutrition to enable schools to provide students with nutritious food and beverage choices while implementing these changes progressively. ${ }^{12}$ These standards provide guidelines that each high school in West Virginia must meet in their school lunches served each day. Some of these guidelines are very specific as to what each meal must consist of: 1 ) include $1 / 3$ of students' Recommended Daily Allowances (RDAs) for calories, protein, calcium, iron, vitamins A and $\mathrm{C}$; 2) limit calories from fat to no more than $30 \%$ and saturated fat to less than $10 \%$; 3) limit sodium to no more than 1,100 milligrams; 4) include at least 6 grams of naturally occurring dietary fiber; and 5) offer water. ${ }^{12}$ This is just one example of West Virginia's standards on school lunches. Each state has established their own guidelines for their school lunch programs.

Most high school students can choose what they eat for lunch, whether they buy a school lunch, bring a brown-bag lunch from home, or eat from an a la carte line; they usually have the final say as to what food they actually consume. Adolescents will make food choices according to what tastes good, the amount of money they have, or in regard to their health. Only one quarter of students reported that they think about their health when making food choices in the school cafeteria. ${ }^{27}$ School lunch habits, like basic nutritional habits need to be taught and emphasized early on to develop healthy habits for life. 
The nutritional needs for growth and development of the adolescent athletes must be placed above athletic considerations. ${ }^{30}$ Adolescent athletes need to pay more attention to their diets than their non-athlete cohorts. The nutritional needs for athletes differ because of the energy they expend playing sports. Meeting energy needs is the first nutrition priority for athletes. Achieving energy balance is essential for the maintenance of lean tissue mass, immune and reproductive function, and optimal athletic performance. $^{13,16,23}$ Energy balance is a state when energy intake equals energy expenditure. ${ }^{13}$ Because of the high amount of energy expended playing sports, athletes need to make sure their intake provides equal amounts of energy through the right foods. To accomplish this, athletes need to first aim to consume the maximum number of servings specified in the Food Guide Pyramid from carbohydrates. ${ }^{13,23}$ Sometimes athletes' energy needs will exceed the amount of energy from the proper diet being consumed. They will then need to increase the servings from the Food Guide Pyramid. ${ }^{10,13}$

Problems may arise among athletes who stray from these basic principles for the latest fad diet promising to give them a competitive edge. Athletes who resort to extreme measures to maintain weight may be prone to disorders related to calcium, pyridoxine, magnesium, zinc, and iron. ${ }^{1}$ Adolescent athletes have a particular need for dietary iron, because they are subject to exercise-related iron losses at the same time they have increased physiologic needs for overall growth. ${ }^{1,23}$

Adolescent athletes have been known to take vitamin or mineral supplements to enhance their athletic performance. Some of these products include vitamins, minerals, sports drinks, and protein shakes. ${ }^{26,31,32}$ The various studies on this subject vary from 
$23-56 \%$ as to how many adolescent athletes actually take these supplements. ${ }^{32}$ Although several studies have shown that taking any of these supplements have no scientific proof that they help with any type of athletic prowess, ${ }^{31,33,34,35}$ most of the athletes taking these various substances were due to the misconception that they would build muscle, improve athletic performance, or help make up for a lack of nutrients in their diets. ${ }^{34}$ The prevalence of supplements seem to rise when talking about college athletes. This could be due to the added pressures of college sports. ${ }^{35}$

High school football is a popular sport that involves high-intensity activity, training, and competition. Because of these high demands placed on them, their nutritional needs will vary considerably depending on their level of participation. ${ }^{16}$ Football causes the athletes to expend more energy than adolescents in the same age group. Because of this football athletes need to consume more calories to make up for this energy expenditure. Proper hydrating habits along with a proper energy intake will provide a good nutritional base for the high school football player. Given that these athletes are highly vulnerable, it is important to provide them with adequate knowledge that will enable them to make healthy dietary choices and to recognize the importance of good nutritional practices. ${ }^{16}$

Nutritional Education

There have been many studies that confirm the need for more nutrition education. ${ }^{4,5,36,37,38}$ Nutritional misconceptions and lack of knowledge among adolescents cause potential public health problems. ${ }^{37}$ Adolescent's principal sources of nutrition knowledge come from the media (television or advertisements), their parents, or their peers. ${ }^{36,37}$ But this information is usually misleading. The media tries to sell their 
product without much regard to anything else. The average youngster in the U.S. see thousands of television commercials yearly, many of which promote foods high in refined sugar. ${ }^{39}$ This misleads adolescents to believe that their product may be healthier then it is, or even mislead one to believe that their product will actually improve athletic performance. ${ }^{5}$ Some things that lead to poor nutritional choices are: 1) a poor understanding of sports nutrition principles; 2) a failure to recognize their individual nutritional requirements; 3) an apparent conflict of nutritional goals; and 4) a lack of practical nutrition knowledge and skills. ${ }^{38}$ This might be related to an apparent lack of nutrition education being taught in school. Because of this lack of knowledge, more education on nutrition in the schools is necessary for adolescents.

Each state has their own rules and guidelines on what classes are required in high school. The state of West Virginia requires at least general health requirements during every year of school from kindergarten through high school. ${ }^{38}$ Students learn about the Food Guide Pyramid, serving sizes, and unhealthy food choices throughout elementary and middle schools. They then learn how to apply this knowledge in everyday life during high school. They learn about the concepts of total wellness, disease, and food shopping. ${ }^{38}$ The standards of health education from Grades 6 through high school are very detailed and are described in Table B4.

This program of study builds on the foundation established in the K-8 health education curriculum and prepares students to become wise health care consumers and responsible, productive citizens. Students examine personal health choices and the connection to the world of work and assumption of adult roles. In-depth analysis of current health issues and concepts coupled with school-wide opportunities that promote 
and reinforce the importance of good health and positive choices need to be coordinated to have the greatest impact on adolescent behavior. ${ }^{38}$ Instruction continues to focus on prevention of all risk behaviors, and may also emphasize limiting the negative consequences of high risk behavior and promote values that are age-appropriate and realistic. However, a single health class in high school may not be enough. Continued nutrition education is very important to build good diet habits. ${ }^{36,37}$

Table B4. West Virginia Nutrition Standards Grades 6 through High School. ${ }^{38}$

\begin{tabular}{ll}
\hline Standard & Description \\
\hline HE.6.1.1 & $\begin{array}{l}\text { Describe the USDA food pyramid, including number and size } \\
\text { of servings and basic nutrients needed for an adolescent } \\
\text { female/male on a daily basis. }\end{array}$ \\
HE.63.3 & $\begin{array}{l}\text { Identify hygiene and food safety practices for improved } \\
\text { personal and family health. }\end{array}$ \\
Analyze the influence that advertisers have on consumer \\
choices (e.g., tobacco, alcohol and other consumer products). \\
Describe the influence of cultural beliefs on health behaviors \\
(e.g., nutrition, hygiene, medical treatment) and the use of \\
health services. \\
Apply the USDA Dietary Guidelines and Food Pyramid in \\
meal planning. \\
Discuss the consequences of poor nutritional choices (e.g., \\
eating disorders) for self and others (e.g., families and babies). \\
HE.7.6.2 \\
Identify and explain the components of total wellness. \\
Apply nutritional concepts to food choices and disease \\
prevention. \\
Identify ways to access current health information and \\
services (e.g., internet) \\
Recognize and report signs of self-destructive behaviors (e.g., \\
suicide, eating disorders, gang membership, anger, \\
depression, anxiety) in others. \\
Recognize bias in advertising and misleading media \\
communication about health information, products, and \\
services. \\
Identify and interpret the effect of media messages on health \\
and nutrition. \\
Identify personal health goals and choose strategies regarding \\
nutrition and alcohol, tobacco, drug use and personal safety to \\
achieve optimal personal health. \\
Discriminate between the positive and potentially negative \\
effects of local and global environmental health problems \\
(e.g. pollution-air, land, water, noise, exposure to sun, \\
pesticides, food production). \\
Identify the factors (e.g., quackery, food labels, media, peers, \\
family) that influence personal choices on health promoting \\
products based on current information. \\
Recognize and demonstrate the positive effects of nutrition \\
and physical activity on health.
\end{tabular}


HE.HS.4.2

HE.HS.5.1

HE.HS.6.1 heart disease, STDs).

Evaluate how media perspectives of health impact on personal, family and community health.

Utilize skills for effective communication in discussions concerning nutrition, sexuality, and relationships with peers, family and others.

Apply a decision-making process to set goals for various life situations (e.g., food choices, weight control, relationships, health care providers, making purchases, education and career options).

\section{Studies on Nutritional Knowledge}

There have been various studies ${ }^{4,5,6,36,37,38,40}$ performed to evaluate the nutritional knowledge of adolescents and athletes. A majority of the studies reported the same conclusion that adolescents need better nutrition education throughout school. Jonnalagadda's ${ }^{16}$ study used a nutritional questionnaire to determine the dietary practices, attitudes, and physiological status of 31 college freshman football players. This study discovered that there is a need for more education on proper eating habits among football players due to their misconceptions on the subject. Forty-two percent of the participants reported using dietary supplements, mostly protein supplements, because they thought they would help with the growth and development of muscle. ${ }^{16}$ Mitchell's ${ }^{3}$ study on high school athlete's nutritional knowledge in a small school in Pennsylvania, indicated that football athletes have the least nutritional knowledge of all of the other sports. The football athletes averaged 13.57 out of a possible 27 points compared with the total average for all the males at the school with 15.07. Another study done by Schmaltz ${ }^{6}$ indicated similar results implicating poor habits regarding diet and nutrition using a questionnaire about basic nutrition information. This study of 381 high school students found that $61 \%$ of the students ate a lunch high in fat. Brook's ${ }^{36}$ study on 141 
high school students found that their knowledge of food consumption and nutrition remains insufficient due to the fact that only $28.3 \%$ of their knowledge was thought to come from school education. The rest of their knowledge came from the media, which is rarely a reliable source. Brook's ${ }^{36}$ questionnaire was comprised of six sections: general information, habits of food consumption, satisfaction with body size, pupil's knowledge concerning food, nutrition and diets, attitudes towards obesity, and sources of information and desire to expand their knowledge.

Werblow ${ }^{4}$ completed a study using 94 females to complete a survey and food pattern document. The results from this study noted that the participants received high scores (average 105 out of a possible 155) on the nutrition survey when talking about nutrition for the athlete, but lower ( $<30 \%$ correct) on the parts regarding basic nutrition. The results showed that women who had a nutrition education class in high school or college scored higher on the test $(\mathrm{P}<0.001)$ then those who did not have a formal nutrition class. $^{4}$ Schwartz ${ }^{35}$ completed a study looking at the relationship between previous enrollment in home economics courses and present nutritional knowledge, attitudes, and practices of high school graduates from Ohio. The study found that graduates had higher mean scores on the nutrition survey than the participants that did not take a home economics course. Pirouznia ${ }^{5}$ also reported similar results with girls scoring higher than boys on nutrition surveys. The girls had an average score of 12.35 compared to the boys with an average score of only 10.86 out of a possible 20 points. ${ }^{5}$ This study used 532 middle school students and reported that the $7^{\text {th }}$ graders scored higher (29.85 out of 30 ) on the CANKAP test than the $8^{\text {th }}$ graders (26.84 out of 30 ), showing that nutrition was not retained from the $7^{\text {th }}$ grade health class. 
Other habits that were recognized as poor diet choices in studies were related to intake of more soft-drinks and pre-sweetened foods and beverages. One such study was done by Frary ${ }^{7}$ using the USDA's CSFII survey. This study concluded that consuming high amounts of pre-sweetened foods and beverages and more soft-drinks were associated with increased intakes of some nutrients. Whole grain consumption has been decreasing over the years. Harnack ${ }^{9}$ found through her study of 4,802 high school students, that the mean average of consumed whole grains was only one serving a day. This is very low compared to the Food Guide Pyramid's recommendation of at least 3 servings of whole grains per day. ${ }^{10}$

The good news about nutritional knowledge among adolescents is that the majority of the participants from these studies expressed the need and desire for more education on nutrition throughout high school. Results from Brook's ${ }^{36}$ study indicated that $79 \%$ of the participants believed the need for more nutrition education in the curriculum. Jonnalagadda's ${ }^{16}$ results also showed an interest and desire for more nutrition education. The football players in that study listed the following interests in Table B5 for further education. Most indicated a desire to learn more about nutrition for peak athletic performance and about weight gain. Tips for eating out was also indicated by many of the football players due to the fact that they ate out often whether being away on road trips or because of living in a college environment. ${ }^{16}$

$\frac{\text { Table B5. Interests of nutrition topics by collegiate freshman football players. }}{{ }^{16}}$

\begin{tabular}{lc}
\hline Nutrition for Peak Performance & 97 \\
Weight Gain & 81 \\
Tips on Eating Out & 71 \\
Exercise and Fitness Programs & 65 \\
Weight Control & 52 \\
Cooking Demonstrations and Meal Preparation & 48 \\
Grocery Store Tour & 39 \\
\hline
\end{tabular}


Kubik completed a study using 350 parents and 490 middle school teachers to assess their views on the student's knowledge of nutrition. ${ }^{25}$ The questionnaire that was used in this study was developed by the researchers to address the respondents' opinions and beliefs regarding the school food environment. ${ }^{25}$ This study found that $87 \%$ of the parents and $95 \%$ of teachers believed that it was important to address eating habits during adolescence. ${ }^{25}$ Fifty-three percent of parents and $67 \%$ of teachers believed that food habits are established before middle school, however, only $12 \%$ of parents and $11 \%$ of teachers believed that the students ate healthful diets. ${ }^{25}$ This emphasizes the need for more education for adolescents but the next step is the actual application of this knowledge. The nutrition knowledge needs to be transferred into better dietary habits to meet the needs of this problem.

Diet Recall

There is an important need to evaluate the knowledge and eating habits of adolescents to understand the request for further nutrition education. There are five commonly used methods for assessing the diet of individuals. ${ }^{41}$ There are advantages and disadvantages for each type of assessment. They are described in Table B6. The dietary assessment methods implemented are retrospective and prospective methods. Retrospective methods of dietary assessment are ones that examine very recent food intake, or less recent intake and are greatly dependent upon the subject's memory and honesty. Prospective methods of dietary assessment are ones that monitor ongoing food consumption, and are mainly tainted by the degree of subject cooperation needed, which often results in a large burden, poor compliance, and alteration of the subject's usual intake. 
Table B6. Dietary assessment methods. ${ }^{41}$

\begin{tabular}{|c|c|c|c|c|}
\hline Method & Description & Advantages & Disadvantages & Applications \\
\hline $\begin{array}{l}\text { Retrospective } \\
\text { Diet Recall }\end{array}$ & $\begin{array}{l}\text { Subject describes all } \\
\text { food and drinks } \\
\text { consumed over the past } \\
24 \text { hours, or in the } \\
\text { preceding day }\end{array}$ & $\begin{array}{l}\text { Easy to administer } \\
\text { Fast to complete } \\
\text { Low respondent burden } \\
\text { Minimal distortion of } \\
\text { food intake } \\
\text { Inexpensive }\end{array}$ & $\begin{array}{l}\text { May not be } \\
\text { representative of usual } \\
\text { intake } \\
\text { Requires a trained } \\
\text { interviewer } \\
\text { Relies on memory }\end{array}$ & $\begin{array}{l}\text { Mainly used to rank } \\
\text { food or nutrient intakes } \\
\text { of groups of people } \\
\text { May not be suitable for } \\
\text { individual assessment } \\
\text { Useful in clinical } \\
\text { settings }\end{array}$ \\
\hline $\begin{array}{c}\text { Food-Frequency } \\
\text { Questionnaire (FFQ) }\end{array}$ & $\begin{array}{l}\text { Subject describes the } \\
\text { frequency of } \\
\text { consumption of specific } \\
\text { food items on a } \\
\text { predetermined list }\end{array}$ & $\begin{array}{l}\text { May be self- } \\
\text { administered } \\
\text { Inexpensive } \\
\text { Believed to assess usual } \\
\text { diet } \\
\text { Can also provide } \\
\text { quantitative information }\end{array}$ & $\begin{array}{l}\text { Respondent burden } \\
\text { rises as the food list } \\
\text { increases } \\
\text { Difficult quantification } \\
\text { of portion sizes } \\
\text { Each questionnaire is } \\
\text { population-specific and } \\
\text { requires validation }\end{array}$ & $\begin{array}{l}\text { Mainly used to detect, } \\
\text { measure, or rank } \\
\text { specific nutrients or } \\
\text { food intakes in groups } \\
\text { or individuals } \\
\text { Used for cross-checking } \\
\text { data obtained from } \\
\text { other methods }\end{array}$ \\
\hline Diet History & $\begin{array}{l}\text { Participants describe all } \\
\text { food and drinks } \\
\text { consumed on a typical } \\
\text { day, completes a Food } \\
\text { Frequency } \\
\text { Questionnaire, and } \\
\text { reports usual menus }\end{array}$ & $\begin{array}{l}\text { Provides information } \\
\text { on both qualitative and } \\
\text { quantitative aspects of } \\
\text { usual diet } \\
\text { Captures day-to-day } \\
\text { and seasonal variations }\end{array}$ & $\begin{array}{l}\text { Requires highly skilled } \\
\text { interviewer } \\
\text { Time-consuming and } \\
\text { resource-demanding } \\
\text { Depends on memory } \\
\text { Relatively expensive to } \\
\text { conduct and analyze }\end{array}$ & $\begin{array}{l}\text { Mainly used to assess } \\
\text { usual intakes of } \\
\text { individuals in clinical } \\
\text { practice } \\
\text { Good for longitudinal } \\
\text { studies }\end{array}$ \\
\hline $\begin{array}{l}\text { Prospective } \\
\text { Weighed Diet Record }\end{array}$ & $\begin{array}{l}\text { Subject weighs items } \\
\text { on a scale and records } \\
\text { all food and drink } \\
\text { consumed; plate waste } \\
\text { is also weighed }\end{array}$ & Increased accuracy & $\begin{array}{l}\text { High respondent burden } \\
\text { Usual intake may be } \\
\text { altered } \\
\text { Expensive and time- } \\
\text { consuming }\end{array}$ & $\begin{array}{l}\text { Mainly used to } \\
\text { determine eating habits } \\
\text { for } 1-7 \text { days } \\
\text { Used for validating } \\
\text { other methods }\end{array}$ \\
\hline Estimated Diet Record & $\begin{array}{l}\text { Subject estimates } \\
\text { portion sizes and } \\
\text { records all food and } \\
\text { drink consumed }\end{array}$ & $\begin{array}{l}\text { Acceptable accuracy } \\
\text { Increased compliance } \\
\text { compared to weighed } \\
\text { record }\end{array}$ & $\begin{array}{l}\text { Compliance decreased } \\
\text { as period of diet } \\
\text { recording increases } \\
\text { Usual intake may be } \\
\text { altered }\end{array}$ & $\begin{array}{l}\text { Mainly used to } \\
\text { determine eating habits } \\
\text { for } 1-7 \text { days }\end{array}$ \\
\hline Duplicate Portion & $\begin{array}{l}\text { Subject collects } \\
\text { duplicate samples from } \\
\text { all food and drink } \\
\text { consumed; these are } \\
\text { subsequently } \\
\text { chemically analyzed for } \\
\text { energy and nutrient } \\
\text { content }\end{array}$ & $\begin{array}{l}\text { Most accurate } \\
\text { Independent of food } \\
\text { database }\end{array}$ & $\begin{array}{l}\text { High respondent burden } \\
\text { Usual intake may be } \\
\text { altered } \\
\text { Chemical analysis of } \\
\text { food is expensive and } \\
\text { time-consuming }\end{array}$ & $\begin{array}{l}\text { Mainly used in } \\
\text { metabolic research } \\
\text { Used for validating } \\
\text { other methods }\end{array}$ \\
\hline
\end{tabular}

Understanding how children and adolescents retain and recall dietary information

is important, not only for identifying the limits of accuracy of recall, but also to guide the

development of strategies for enhancing accuracy of recall. ${ }^{40}$ The one problem that has

been shown with diet recall is that children and adolescents cannot remember the foods

that they have eaten. Weber and colleges ${ }^{21}$ have found this to not be the case. This study

used 80 third grade students and found that $75 \%$ of the children were able to correctly

recall the foods they were observed consuming, and correctly recalled $83 \%$ of foods by 
food group. Greger ${ }^{19}$ conducted a study on 24 hour diet recalls and tested 32 adolescent girls in a 30 day metabolic study. This study reported different results and indicated that the participants would miss food on a recall that they ate, rather than add wrong items or miss-identify foods. The Centers for Disease Control and Prevention completes a Youth Risk Behavior Survey each year to evaluate the risks involved with adolescent's choice of diet and exercise. ${ }^{11}$ The survey includes information regarding diet, exercise, lifestyle habits, eating disorders, and much more.

The type of diet recall to choose depends on the type of information sought, as well as the resources available. The population of the participants being tested is also very important when choosing the method to evaluate nutrition knowledge and dietary habits. ${ }^{18}$ Some questionnaires are not specific for children or adolescents, rather for adults. These surveys would not be suitable to test the knowledge of adolescents.

The USDA developed a measure of overall diet quality called the Healthy Eating Index (HEI). This was developed in an attempt to measure how well Americans are meeting current dietary recommendations. ${ }^{21,42}$ The HEI is a measure of diet quality that is both food and nutrient based. One disadvantage to this method is that it was developed for anyone who was 2 years old or older. However, studies have shown that food choices are often influenced by sociodemographic variables such as age, gender, ethnicity, and socioeconomic status and would therefore not be suitable to test children or adolescents. ${ }^{21}$ Feskanich and colleges ${ }^{42}$ have made an attempt to correct this problem. They have developed the Youth Healthy Eating Index (YHEI) dietary scoring system by modifying the HEI to better address dietary issues particular to older children and adolescents and to be simple enough for their individual use. Like the HEI, the YHEI focuses on the same 
data. It looks at total fat, saturated fat, and sodium in the diet by examining food choices rather than by directly calculating the nutrient intakes. The YHEI also included more food that children and adolescents were more likely to consume like potato chips, and soda. When tested against each other, the HEI was found to be highly correlated with total energy intake $(r=0.67)$, indicating a strong association with quantity of food consumption. The YHEI was primarily associated inversely with time spent in inactive pursuits. The conclusion of this study was that the HEI was an appropriate tool to use while testing adults, but to assess children and adolescents, modifications needed to be made to accommodate the special needs of the younger population.

The Eating Habits Questionnaire (EHQ) another type of diet recall device was used in a limited number of studies. The purpose of the EHQ is to assess eating habits, including eating patterns based on the Food Guide Pyramid, as well as total energy intake and percentage of calories from the major nutrient categories: protein, carbohydrates, and fat. $^{8} \quad$ Advantages of this recall include practicality and acceptable reliability and validity that have been determined in an ethnically diverse sample of middle school youth. Speck ${ }^{8}$ completed a study using the EHQ with 446 middle school students and found that it was a valid and reliable food frequency questionnaire (FFQ) that has been tested for adolescents. Results from this study concluded that adolescents consumed higher than recommended daily servings for fats, sweets, and meats and lower than recommended servings of vegetables and breads. The Youth-Adolescent Questionnaire (YAQ) is a update of an older child based nutrition questionnaire that now includes a separate snack section of 27 items. ${ }^{43}$ These snack foods are more up-to-date choices for children and adolescents. Another newer type of diet recall was developed so that the questionnaire is 
administered on the computer. This new technology-friendly questionnaire could be used in a school or clinical setting, rather than out in the field. The Young Adolescents' Nutrition Assessment on the Computer (YANA-C) is one type of a computer test that was compared with food records and a 24 hour diet recall in Vereecken's study. ${ }^{22}$ The YANA-C agreed well with both methods in categorizing participants into consumers and non-comsumers. ${ }^{43}$ This new type of diet recall would be very helpful for research studies on nutritional application.

Summary

Adolescent athletes lack the proper knowledge of nutrition and live with unhealthy eating habits. This problem can affect their athletic performance and lead to unhealthy lifestyles. Recent research suggests that the adolescent athlete is neither aware nor prepared for the dual demands of sound nutritional practices in general and those demanded by his or her chosen sport activities. The problem with athletes not eating proper amounts of certain nutrients is that their energy requirements are not met. This problem can be solved by following the USDA requirements for all food groups.

High school football players need to be better educated on proper nutrition in order to apply this knowledge into their own lifestyles. It has been shown that the diet for the average adolescent is comprised of mostly junk food, with very little consumption fruits, vegetables, and whole grains. The various diet recalls available to test nutrition knowledge and diet habits can help assess the need for better education and better emphasis of diet habits for any group of individuals. The diet recall needs to be selected to accommodate the participants, information being evaluated, and the resources 
available to the researcher. The diet recalls are adequate tools to assess the needs of nutrition knowledge and dietary habits of athletes and adolescents alike. 


\section{APPENDIX C}

\section{ADDITIONAL METHODS}

\section{Table C1: Cover Letter}

October 3, 2005

Dear Grafton High School Football Athlete,

I am a West Virginia University graduate athletic training student and I am conducting research on the nutritional knowledge and application of high school football players. The purpose of this study is to determine if high school football players have proper nutrition knowledge and are applying this knowledge in their food choices. This research is being conducted to partially fulfill the requirements for the completion of the Master of Science degree in Athletic Training.

The following questionnaire includes 8 demographic questions and 27 multiple choice and true/false questions regarding general nutritional knowledge. The diet recall consists of 15 multiple choice questions regarding the foods you have eaten in the last 7 days. The questionnaire should take approximately 20 minutes to complete. If there is any information you feel was left out of the questionnaire or any comments that you wish to make, please feel free to include them when returning the questionnaire and diet recall.

Coding will be used to keep track of your responses, but your name will not be associated with your responses. I will be the only person with access to the information provided. Your responses will remain anonymous and confidential. Participation in this study is completely voluntary and you are not required to answer every question. Your grades, position on the team, nor injury evaluation, and treatment will not be affected by refusing to participate. You have the right to withdrawal any data you submit at any time. Completing and returning this questionnaire and diet recall will serve as your consent to participate. If you choose to participate, please complete the questionnaire and diet recall and return the questionnaire in the folder at the front of the room.

If you have any questions or concerns, please feel free to contact Kimberly A. Molnar by phone at (814) 243-4397 or via email at kmolnar@mix.wvu.edu. You may also contact my supervisor, Dr. Michelle Sandrey at (304) 293-3295 x 5220 or msandrey@,mail.wvu.edu with any questions regarding this research.

Thank you in advance for your participation.

Sincerely

Kimberly A. Molnar, ATC

* This study was approved by the Institutional Review Board (IRB) of West Virginia University and the School of Physical Education. 
Table C2.: Questionnaire

Demographic Information Code:

Please answer the following questions by circling the answer or filling in the blank space.

1. Year in School: Freshman Sophomore Junior Senior

2. Age:

3. How many years have you played football?

4. What year in school were you when you took a health class? Freshman Sophomore Junior Senior Have not taken it yet

5. Did/do you talk about nutrition in that health class? Yes No

6. Do you eat breakfast on all or most days? Yes No

7. Do you eat school lunches? Yes No

8. On a typical day, how many times would you eat a meal? A snack? 


\section{Nutrition Knowledge Questionnaire}

Please circle the response option that you believe is the best answer to each of the following questions.

1. The main energy source for athletes is
A. Carbohydrates
B. Proteins
C. Fats

2. Carbohydrates and protein have the same caloric value.
A. True
B. False

3. Eating a lot of food with high amounts of protein increases muscle size?
A. True
B. False

4. Protein is the primary source of energy for muscles.
A. True
B. False

5. The Food Guide Pyramid recommends a male your age should consume serving(s) a day from the Protein group?
A. Unlimited
B. 1
C. 2

6. A serving size for the protein group is
A. 3 oz. meat
B. 5 eggs
C. 1 tablespoon peanut butter
D. All of the above

7. The Food Guide Pyramid recommends 6-11 servings from the Bread/Cereal group.
A. True
B. False

8. A serving size for the Bread/Cereal group is
A. one slice of bread
B. $1 / 2$ cup of rice
C. $3 / 4$ cup of cereal
D. All of the above

9. Fruits and vegetables are important because they provide vitamins and minerals.
A. True
B. False 
10. The Food Guide Pyramid recommends a male your age should consume servings of vegetables a day.
A. $2-4$
B. $3-5$
C. unlimited

11. A serving size for the vegetable groups is
A. 1 cup carrots
B. 2 cups lettuce
C. $1 / 2$ cup green beans
D. All of the above

12. The Food Guide Pyramid recommends a male your age should consume servings of fruits a day.
A. $3-5$
B. $1-3$
C. $2-4$

13. A serving size for the fruit group is
A. 10 grapes
B. 1 cup applesauce
C. $16 \mathrm{oz}$. orange juice
D. 1 piece of fresh fruit

14. The Food Guide Pyramid recommends servings of calcium rich foods be consumed daily.
A. As many as possible
B. 3
C. 2

15. A serving size for the Dairy group is
A. 8 oz milk
B. 2 cups yogurt
C. 2 oz. cheese
D. All of the above

16. Orange juice is one of the best food sources of Vitamin C.
A. True
B. False

17. A good source of Vitamin A is
A. Carrots
B. Potatoes
C. Celery

18. What is the first step to take to lose weight?
A. Stop drinking water
B. Skip meals
C. Decrease the consumption of sweets, pastries, candy, etc. 
19. A proper diet consists of $50-65 \%$ carbohydrates, less than $30 \%$ fat, and $12-15 \%$ protein.
A. True
B. False

20. The type of food eaten affects athletic performance.
A. True
B. False

21. A diet low in cholesterol and saturated fat may help prevent heart disease.
A. True
B. False

22. While in football season, athletes need to eat at least 3 times a day.
A. True
B. False

23. A pre-game meal should consist of a meal easy to digest, low in fat, high in carbohydrates and be eaten 2-3 hours before the event.
A. True
B. False

24. You should drink fluids before, during, and after practices and competitions.
A. True
B. False

25. Athletes should rely on thirst to ensure fluid replacement during and after competitions.
A. True
B. False

26. Gatorade and other sports drinks are better than water for replacing fluids lost during practices and competition.
A. True
B. False

27. Butter, potato chips, and soda should be consumed
A. Unlimited
B. Often
C. Sparingly 
Table C4: Diet Recall

Diet Recall Questionnaire.

Code:

The following 15 questions ask about food you ate or drank during the past 7 days. Think about all the meals and snacks you had from the time you got up until you went to bed. Be sure to include food you ate at home, at school, at restaurants, or anywhere else. Circle the best answer for each question.

1. During the past 7 days, how many times did you drink $\mathbf{1 0 0} \%$ fruit juices such as orange juice, apple juice, or grape juice? (Do not count punch, Kool-Aid, sports drinks, or other fruit-flavored drinks.)
A. I did not drink $100 \%$ fruit juice during the past 7 days
B. 1 to 3 times during the past 7 days
C. 4 to 6 times during the past 7 days
D. 1 time per day
E. 2 times per day
F. 3 times per day
G. 4 or more times per day

2. During the past 7 days, how many times did you eat fruit? (Do not count fruit juice.)
A. I did not eat fruit during the past 7 days
B. 1 to 3 times during the past 7 days
C. 4 to 6 times during the past 7 days
D. 1 time per day
E. 2 times per day
F. 3 times per day
G. 4 or more times per day

3. During the past 7 days, how many times did you eat a salad?
A. I did not eat a salad during the past 7 days
B. 1 to 3 times during the past 7 days
C. 4 to 6 times during the past 7 days
D. 1 time per day
E. 2 times per day
F. 3 times per day
G. 4 or more times per day

4. During the past 7 days, how many times did you eat potatoes? (Do not count French fries, fried potatoes, or potato chips.)
A. I did not eat potatoes during the past 7 days
B. 1 to 3 times during the past 7 days
C. 4 to 6 times during the past 7 days
D. 1 time per day
E. 2 times per day
F. 3 times per day
G. 4 or more times per day

5. During the past 7 days, how many times did you eat carrots?
A. I did not eat carrots during the past 7 days
B. 1 to 3 times during the past 7 days
C. 4 to 6 times during the past 7 days
D. 1 time per day
E. 2 times per day
F. 3 times per day
G. 4 or more times per day 
6. During the past 7 days, how many times did you eat other vegetables? (Do not count salad, potatoes, or carrots.)

A. I did not eat other vegetables during the past 7 days

B. 1 to 3 times during the past 7 days

C. 4 to 6 times during the past 7 days

D. 1 time per day

E. 2 times per day

F. 3 times per day

G. 4 or more times per day

7. During the past 7 days, how many glasses of milk did you drink? (Include the milk you drank in a glass or cup, from a carton, or with cereal. Count the half pint of milk served at school as equal to one glass.)
A. I did not drink milk during the past 7 days
B. 1 to 3 glasses during the past 7 days
C. 4 to 6 glasses during the past 7 days
D. 1 glass per day
E. 2 glasses per day
F. 3 glasses per day
G. 4 or more glasses per day

8. During the past 7 days, how many times did you eat chicken, fish, or red meat? (Do not count any fast food hamburgers or sandwiches.)
A. I did not eat chicken, fish, or red meat during the past 7 days
B. 1 to 3 times during the past 7 days
C. 4 to 6 times during the past 7 days
D. 1 time per day
E. 2 times per day
F. 3 times per day
G. 4 or more times per day

9. During the past 7 days, how many times did you eat other types of protein? (Include beans, peanut butter, peas, nuts, or seeds. Do not count chicken, fish, or red meat.)
B. 1 to 3 times during the past 7 days
C. 4 to 6 times during the past 7 days
D. 1 time per day
E. 2 times per day
F. 3 times per day
G. 4 or more times per day

A. I did not eat other types of protein during the past 7 days

10. During the past 7 days, how many times did you eat bread or cereal?
A. I did not eat bread or cereal during the past 7 days
B. 1 to 3 times during the past 7 days
C. 4 to 6 times during the past 7 days
D. 1 time per day
E. 2 times per day
F. 3 times per day
G. 4 or more times per day 
11. During the past 7 days, how many times did you eat other types of grains? (Include crackers, pasta, rice, etc. Do not include bread or cereal.)

A. I did not eat other types of grains during the past 7 days

B. 1 to 3 times during the past 7 days

C. 4 to 6 times during the past 7 days

D. 1 time per day

E. 2 times per day

F. 3 times per day

G. 4 or more times per day

12. During the past 7 days, how many times did you eat fast food? (Include any type of fast food restaurant that you visited.)

A. I did not eat fast food during the past 7 days

B. 1 to 3 times during the past 7 days

C. 4 to 6 times during the past 7 days

D. 1 time per day

E. 2 times per day

F. 3 times per day

G. 4 or more times per day

13. During the past 7 days, how many glasses of soda did you drink? (Count one $12 \mathrm{oz}$. can of soda or a 16 oz bottle as one glass.)

A. I did not drink soda during the past 7 days

B. 1 to 3 glasses during the past 7 days

C. 4 to 6 glasses during the past 7 days

D. 1 glass per day

E. 2 glasses per day

F. 3 glasses per day

G. 4 or more glasses per day

14. During the past 7 days, how many times did you eat any type of junk food? (Include any of the following candy, potato chips, or cookies)

A. I did not eat junk food during the past 7 days

B. 1 to 3 times during the past 7 days

C. 4 to 6 times during the past 7 days

D. 1 time per day

E. 2 times per day

F. 3 times per day

G. 4 or more times per day

15. During the past 7 days, how many glasses of water did you drink? (Count an $8 \mathrm{oz}$. glass of water as one glass or a $16 \mathrm{oz}$ bottle as 2 glasses.)

A. I did not drink water during the past 7 days

B. 1 to 3 glasses during the past 7 days

C. 4 to 6 glasses during the past 7 days

D. 1 glass per day

E. 2 glasses per day

F. 3 glasses per day

G. 4 or more glasses per day 


\section{APPENDIX D}

\section{ADDITIONAL RESULTS}

Table D1. Descriptive Statistics for the Total Correct

\begin{tabular}{lccc}
\multicolumn{1}{c}{ Year in School } & Mean & Std. Deviation & N \\
Freshman & 15.083 & 2.888 & 24 \\
Sophomore & 19.000 & 2.677 & 13 \\
Junior & 15.455 & 5.184 & 11 \\
Senior & 17.889 & 1.965 & 9 \\
\hline
\end{tabular}

Table D2. ANOVA Results for the Total Correct on the Nutritional Knowledge Questionnaire.

\begin{tabular}{ccccccc}
\hline & $\begin{array}{c}\text { Sum of } \\
\text { Squares }\end{array}$ & df & Mean Square & F & Sig. & $\beta$ \\
\hline YEAR & 158.796 & 3 & 52.932 & 4.858 & $.005^{*}$ & .885 \\
\hline
\end{tabular}

*. The mean difference is significant at the .05 level.

Table D3. Tukey Post Hoc Results for the Total Correct on the Nutritional Knowledge Questionnaire.

\begin{tabular}{llc}
\hline Year in School & & Significance \\
\hline Freshman & Sophomore & $.006^{*}$ \\
& Junior & .990 \\
Sophomore & Senior & .144 \\
& Junior & .054 \\
Junior & Senior & .865 \\
\hline
\end{tabular}

*. The mean difference is significant at the .05 level.

Table D4. Descriptive Statistics for the Total Correct of the 5 Groupings

\begin{tabular}{lccccc}
\hline \multicolumn{1}{c}{ Year in School } & Freshman & Sophomore & Junior & Senior & Total \\
\hline Grouping & & & & & \\
G1 & $3.208 \pm 1.063$ & $4.615 \pm 1.446$ & $4.182 \pm 1.401$ & $3.556 \pm 1.333$ & $3.772 \pm 1.363$ \\
G2 & $2.375 \pm .924$ & $3.231 \pm 1.013$ & $2.455 \pm 1.440$ & $2.333 \pm .707$ & $2.579 \pm 1.068$ \\
G3 & $1.875 \pm .899$ & $2.923 \pm .954$ & $2.091 \pm 1.375$ & $2.556 \pm .527$ & $2.263 \pm 1.044$ \\
G4 & $5.417 \pm 1.381$ & $6.077 \pm 1.188$ & $4.546 \pm 1.916$ & $6.778 \pm .667$ & $5.614 \pm 1.521$ \\
G5 & $2.208 \pm .932$ & $2.154 \pm .689$ & $2.182 \pm .982$ & $2.556 \pm .726$ & $2.246 \pm .851$ \\
\hline
\end{tabular}

Key: G1=Carbohydrates and Protein, Questions \#1-8, G2=Fruits and Vegetables, Questions \#9-13, G3=Vitamins and Minerals, Questions \#14-17, G4=Diet, Questions \#18-23 and \#27, G5=Hydration, Questions \#24-26. 
Table D5. MANOVA Results for the Total Correct of the 5 Groupings.

\begin{tabular}{lcccccc}
\hline & $\begin{array}{c}\text { Sum of } \\
\text { Squares }\end{array}$ & df & Mean Square & F & Sig. & $\beta$ \\
\hline Total Correct G1 & 19.141 & 3 & 6.380 & 3.983 & $.012^{*}$ & .808 \\
Total Correct G2 & 7.235 & 3 & 2.412 & 2.256 & .093 & .539 \\
Total Correct G3 & 10.373 & 3 & 3.458 & 3.616 & $.019^{*}$ & .765 \\
Total Correct G4 & 28.470 & 3 & 9.490 & 4.978 & $.004 *$ & .893 \\
Total Correct G5 & 1.052 & 3 & .351 & .470 & .704 & .139 \\
\hline
\end{tabular}

*. The mean difference is significant at the .05 level.

Table D6. Tukey Post Hoc Results for Group 1.

\begin{tabular}{llc}
\hline Year in School & & Significance \\
\hline Freshman & Sophomore & $.011^{*}$ \\
& Junior & .162 \\
Sophomore & Senior & .896 \\
& Junior & .837 \\
Junior & Senior & .228 \\
\hline
\end{tabular}

*. The mean difference is significant at the .05 level.

Table D7. Tukey Post Hoc Results for Group 2.

\begin{tabular}{llc}
\hline Year in School & & Significance \\
\hline Freshman & Sophomore & .089 \\
& Junior & .997 \\
Sophomore & Senior & 1.000 \\
& Junior & .270 \\
Junior & Senior & .200 \\
& Senior & .994 \\
\hline
\end{tabular}

Table D8. Tukey Post Hoc Results for Group 3.

\begin{tabular}{llc}
\hline Year in School & & Significance \\
\hline Freshman & Sophomore & $.015^{*}$ \\
& Junior & .930 \\
Sophomore & Senior & .294 \\
& Junior & .174 \\
Junior & Senior & .822 \\
\hline
\end{tabular}

*. The mean difference is significant at the .05 level. 
Table D9. Tukey Post Hoc Results for Group 4.

\begin{tabular}{llc}
\hline Year in School & & Significance \\
\hline Freshman & Sophomore & .512 \\
& Junior & .317 \\
Sophomore & Senior & .068 \\
& Junior & $.044^{*}$ \\
Junior & Senior & .648 \\
& Senior & $.004^{*}$ \\
\hline
\end{tabular}

*. The mean difference is significant at the .05 level.

Table D10. Tukey Post Hoc Results for Group 5.

\begin{tabular}{llc}
\hline Year in School & & Significance \\
\hline Freshman & Sophomore & .998 \\
& Junior & 1.000 \\
Sophomore & Senior & .733 \\
& Junior & 1.000 \\
Junior & Senior & .707 \\
\hline
\end{tabular}

Table D11. MANOVA Results for the Diet Recall.

\begin{tabular}{lcccccc}
\hline & $\begin{array}{c}\text { Sum of } \\
\text { Squares }\end{array}$ & df & $\begin{array}{c}\text { Mean } \\
\text { Square }\end{array}$ & F & Sig. & $\beta$ \\
\hline Diet Recall \#1 & 3.961 & 3 & 1.320 & .768 & .517 & .204 \\
Diet Recall \#2 & 12.793 & 3 & 4.264 & 1.967 & .130 & .479 \\
Diet Recall \#3 & 9.455 & 3 & 3.152 & 1.485 & .229 & .370 \\
Diet Recall \#4 & 1.246 & 3 & .415 & .173 & .914 & .808 \\
Diet Recall \#5 & 15.036 & 3 & 5.012 & 1.913 & .139 & .467 \\
Diet Recall \#6 & 1.823 & 3 & .608 & .316 & .813 & .107 \\
Diet Recall \#7 & 30.224 & 3 & 10.075 & 3.991 & $.012 *$ & .809 \\
Diet Recall \#8 & 5.896 & 3 & 1.965 & .897 & .449 & .233 \\
Diet Recall \#9 & .947 & 3 & .316 & .138 & .937 & .074 \\
Diet Recall \#10 & 6.052 & 3 & 2.017 & .749 & .528 & .199 \\
Diet Recall \#11 & 11.721 & 3 & 3.907 & 1.779 & .162 & .437 \\
Diet Recall \#12 & 15.702 & 3 & 5.234 & 2.303 & .088 & .549 \\
Diet Recall \#13 & 13.218 & 3 & 4.406 & 1.439 & .242 & .360 \\
Diet Recall \#14 & 8.956 & 3 & 2.985 & 1.050 & .378 & .269 \\
Diet Recall \#15 & .857 & 3 & .286 & .077 & .972 & .063 \\
\hline$*$ The
\end{tabular}

*. The mean difference is significant at the .05 level. 
Table D12. Tukey Post Hoc Responses for Diet Recall Question 1.

\begin{tabular}{llc}
\hline Year in School & & Significance \\
\hline Freshman & Sophomore & .909 \\
& Junior & .536 \\
Sophomore & Senior & .998 \\
& Junior & .919 \\
Junior & Senior & .906 \\
\hline
\end{tabular}

Table D13. Tukey Post Hoc Responses for Diet Recall Question 2.

\begin{tabular}{llc}
\hline Year in School & & Significance \\
\hline Freshman & Sophomore & .847 \\
& Junior & .154 \\
Sophomore & Senior & .327 \\
& Junior & .619 \\
Junior & Senior & .807 \\
\hline
\end{tabular}

Table D14. Tukey Post Hoc Responses for Diet Recall Question 3.

\begin{tabular}{llc}
\hline Year in School & & Significance \\
\hline Freshman & Sophomore & .827 \\
& Junior & 1.000 \\
Sophomore & Senior & .201 \\
& Junior & .913 \\
Junior & Senior & .677 \\
\hline
\end{tabular}

Table D15. Tukey Post Hoc Responses for Diet Recall Question 4.

\begin{tabular}{llc}
\hline Year in School & & Significance \\
\hline Freshman & Sophomore & .996 \\
& Junior & .889 \\
Sophomore & Senior & .994 \\
& Junior & .969 \\
Junior & Senior & 1.000 \\
\hline
\end{tabular}


Table D16. Tukey Post Hoc Responses for Diet Recall Question 5.

\begin{tabular}{llc}
\hline Year in School & & Significance \\
\hline Freshman & Sophomore & .650 \\
& Junior & 1.000 \\
Sophomore & Senior & .132 \\
& Junior & .801 \\
Junior & Senior & .708 \\
\hline
\end{tabular}

Table D17. Tukey Post Hoc Responses for Diet Recall Question 6.

\begin{tabular}{llc}
\hline Year in School & & Significance \\
\hline Freshman & Sophomore & .994 \\
& Junior & 1.000 \\
Sophomore & Senior & .856 \\
& Junior & .999 \\
Junior & Senior & .792 \\
\hline
\end{tabular}

Table D18. Tukey Post Hoc Responses for Diet Recall Question 7.

\begin{tabular}{llc}
\hline Year in School & & Significance \\
\hline Freshman & Sophomore & .241 \\
& Junior & .995 \\
Sophomore & Senior & $.024^{*}$ \\
& Junior & .282 \\
Junior & Senior & .658 \\
& Senior & $.039^{*}$ \\
\hline
\end{tabular}

*. The mean difference is significant at the .05 level.

Table D19. Tukey Post Hoc Responses for Diet Recall Question 8.

\begin{tabular}{llc}
\hline Year in School & & Significance \\
\hline Freshman & Sophomore & .959 \\
& Junior & .923 \\
Sophomore & Senior & .674 \\
& Junior & .999 \\
Junior & Senior & .498 \\
\hline
\end{tabular}


Table D20. Tukey Post Hoc Responses for Diet Recall Question 9.

\begin{tabular}{llc}
\hline Year in School & & Significance \\
\hline Freshman & Sophomore & .990 \\
& Junior & .961 \\
Sophomore & Senior & .948 \\
& Junior & .998 \\
Junior & Senior & .995 \\
\hline
\end{tabular}

Table D21. Tukey Post Hoc Responses for Diet Recall Question 10.

\begin{tabular}{llc}
\hline Year in School & & Significance \\
\hline Freshman & Sophomore & .522 \\
& Junior & .999 \\
Sophomore & Senior & .844 \\
& Junior & .733 \\
Junior & Senior & .985 \\
& Senior & .931 \\
\hline
\end{tabular}

Table D22. Tukey Post Hoc Responses for Diet Recall Question 11.

\begin{tabular}{llc}
\hline Year in School & & Significance \\
\hline Freshman & Sophomore & .120 \\
& Junior & .834 \\
Sophomore & Senior & .660 \\
& Junior & .659 \\
Junior & Senior & .873 \\
& Senior & .989 \\
\hline
\end{tabular}

Table D23. Tukey Post Hoc Responses for Diet Recall Question 12.

\begin{tabular}{llc}
\hline Year in School & & Significance \\
\hline Freshman & Sophomore & .965 \\
& Junior & .195 \\
Sophomore & Senior & .496 \\
& Junior & .141 \\
Junior & Senior & .361 \\
\hline
\end{tabular}


Table D24. Tukey Post Hoc Responses for Diet Recall Question 13.

\begin{tabular}{llc}
\hline Year in School & & Significance \\
\hline Freshman & Sophomore & .641 \\
& Junior & .905 \\
Sophomore & Senior & .205 \\
& Junior & .980 \\
Junior & Senior & .827 \\
\hline
\end{tabular}

Table D25. Tukey Post Hoc Responses for Diet Recall Question 14.

\begin{tabular}{llc}
\hline Year in School & & Significance \\
\hline Freshman & Sophomore & .814 \\
& Junior & .757 \\
Sophomore & Senior & .906 \\
& Junior & .377 \\
Junior & Senior & 1.000 \\
\hline
\end{tabular}

Table D26. Tukey Post Hoc Responses for Diet Recall Question 15.

\begin{tabular}{llc}
\hline Year in School & & Significance \\
\hline Freshman & Sophomore & 1.000 \\
& Junior & .973 \\
Sophomore & Senior & .991 \\
& Junior & .989 \\
Junior & Senior & .997 \\
& Senior & 1.000 \\
\hline
\end{tabular}


Table D27. Responses to Diet Recall Questions 1-15.

\begin{tabular}{|c|c|c|c|c|c|c|c|}
\hline Questions & A & B & $\mathrm{C}$ & $\mathrm{D}$ & $\mathrm{E}$ & $\mathrm{F}$ & $\mathrm{G}$ \\
\hline $1 *$ & $8.8 \%(n=5)$ & $22.8 \%(n=13)$ & $24.6 \%(n=14)$ & $22.8 \%(n=13)$ & $19.3 \%(n=11)$ & $1.8 \%(\mathrm{n}=1)$ & \\
\hline 2 & $5.3 \%(n=3)$ & $21.1 \%(n=12)$ & $26.3 \%(n=15)$ & $19.3 \%(n=11)$ & $15.8 \%(n=9)$ & $8.8 \%(n=5)$ & $3.5 \%(n=2)$ \\
\hline $3 *$ & $26.3 \%(n=15)$ & $29.8 \%(n=17)$ & $7.0 \%(n=4)$ & $22.8 \%(n=13)$ & $12.3 \%(n=7)$ & $1.8 \%(n=1)$ & \\
\hline $4^{+}$ & $12.3 \%(\mathrm{n}=7)$ & $28.1 \%(n=16)$ & $26.3 \%(\mathrm{n}=15)$ & $15.8 \%(\mathrm{n}=9)$ & $12.3 \%(\mathrm{n}=7)$ & & $5.3 \%(n=3)$ \\
\hline 5 & $36.8 \%(n=21)$ & $31.6 \%(n=18)$ & $8.8 \%(n=5)$ & $8.8 \%(n=5)$ & $7.0 \%(n=4)$ & $3.5 \%(\mathrm{n}=2)$ & $3.5 \%(n=2)$ \\
\hline $6^{*}$ & $15.8 \%(\mathrm{n}=9)$ & $17.5 \%(\mathrm{n}=10)$ & $19.3 \%(\mathrm{n}=11)$ & $31.6 \%(n=18)$ & $14.0 \%(\mathrm{n}=8)$ & $1.8 \%(n=1)$ & \\
\hline 7 & $12.3 \%(n=7)$ & $3.5 \%(n=2)$ & $24.6 \%(n=14)$ & $17.5 \%(n=10)$ & $24.6 \%(n=14)$ & $8.8 \%(n=5)$ & $8.8 \%(n=5)$ \\
\hline 8 & $3.5 \%(n=2)$ & $19.3 \%(\mathrm{n}=11)$ & $21.1 \%(\mathrm{n}=12)$ & $24.6 \%(\mathrm{n}=14)$ & $21.1 \%(n=12)$ & $5.3 \%(\mathrm{n}=3)$ & $5.3 \%(n=3)$ \\
\hline 9 & $5.3 \%(n=3)$ & $21.1 \%(\mathrm{n}=12)$ & $24.6 \%(n=14)$ & $21.1 \%(n=12)$ & $15.8 \%(\mathrm{n}=9)$ & $10.5 \%(n=6)$ & $1.8 \%(\mathrm{n}=1)$ \\
\hline 10 & $5.3 \%(n=3)$ & $8.8 \%(n=5)$ & $21.1 \%(n=12)$ & $22.8 \%(n=13)$ & $22.8 \%(n=13)$ & $7.0 \%(n=4)$ & $12.3 \%(n=7)$ \\
\hline 11 & $3.5 \%(n=2)$ & $29.8 \%(\mathrm{n}=17)$ & $26.3 \%(\mathrm{n}=15)$ & $12.3 \%(\mathrm{n}=7)$ & $17.5 \%(\mathrm{n}=10)$ & $7.0 \%(n=4)$ & $3.5 \%(n=2)$ \\
\hline 12 & $24.6 \%(n=14)$ & $47.4 \%(n=27)$ & $10.5 \%(n=6)$ & $5.3 \%(n=3)$ & $3.5 \%(n=2)$ & $5.3 \%(n=3)$ & $3.5 \%(n=2)$ \\
\hline 13 & $26.3 \%(n=15)$ & $31.6 \%(n=18)$ & $12.3 \%(\mathrm{n}=7)$ & $12.3 \%(n=7)$ & $8.8 \%(n=5)$ & $1.8 \%(n=1)$ & $7.0 \%(n=4)$ \\
\hline 14 & $7.0 \%(n=4)$ & $26.3 \%(n=15)$ & $19.3 \%(n=11)$ & $15.8 \%(n=9)$ & $17.5 \%(n=10)$ & $7.0 \%(n=4)$ & $7.0 \%(n=4)$ \\
\hline 15 & $5.3 \%(n=3)$ & $14.0 \%(n=8)$ & $17.5 \%(n=10)$ & $10.5 \%(n=6)$ & $17.5 \%(n=10)$ & $17.5 \%(n=10)$ & $17.5 \%(n=10)$ \\
\hline
\end{tabular}

*. Questions \#1, \#3, and \#6 did not have a $\mathrm{G}$ response and +. Question \#4 did not have an F response. 
Figure D1. Response of Diet Recall: 100\% Fruit Juice (Question 1).

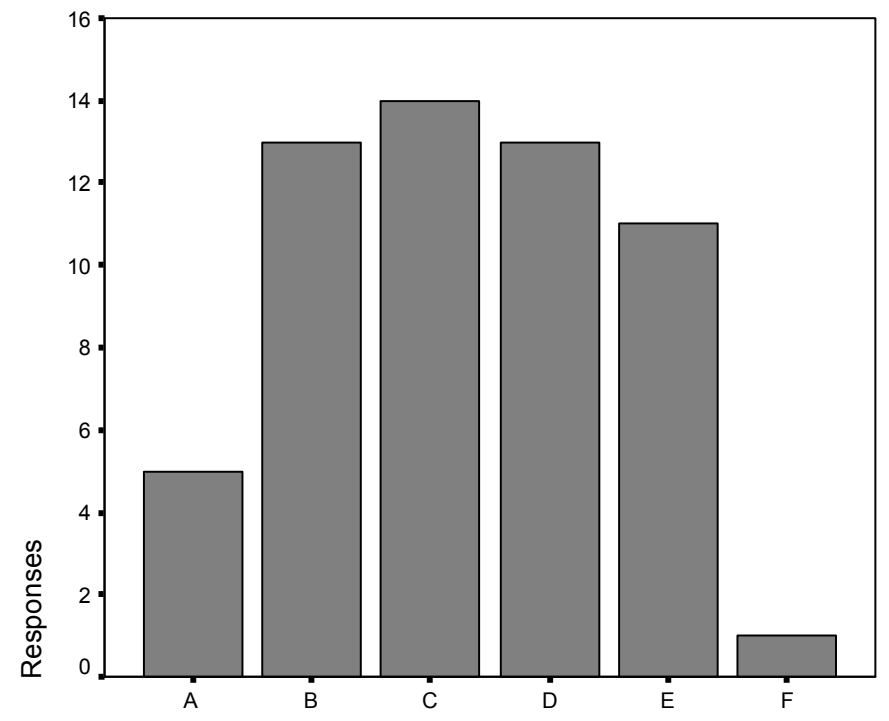

Key: No participants responded with G.

Figure D2. Response to Diet Recall: Fruit (Question 2).

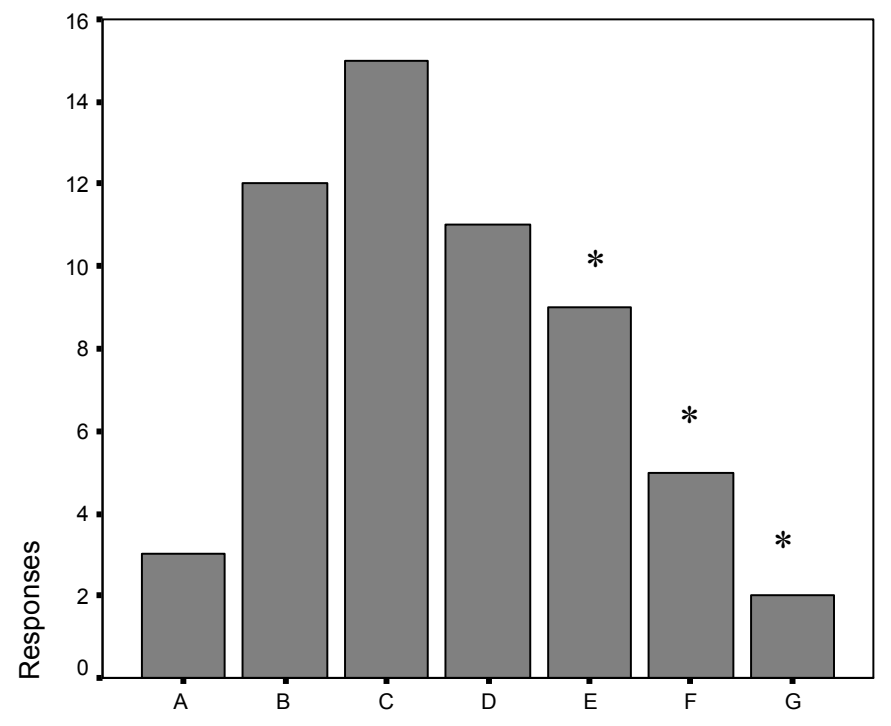

*. Indicates the Recommended Servings for Adolescents ${ }^{20}$ 
Figure D3. Response to Diet Recall: Salad (Question 3).

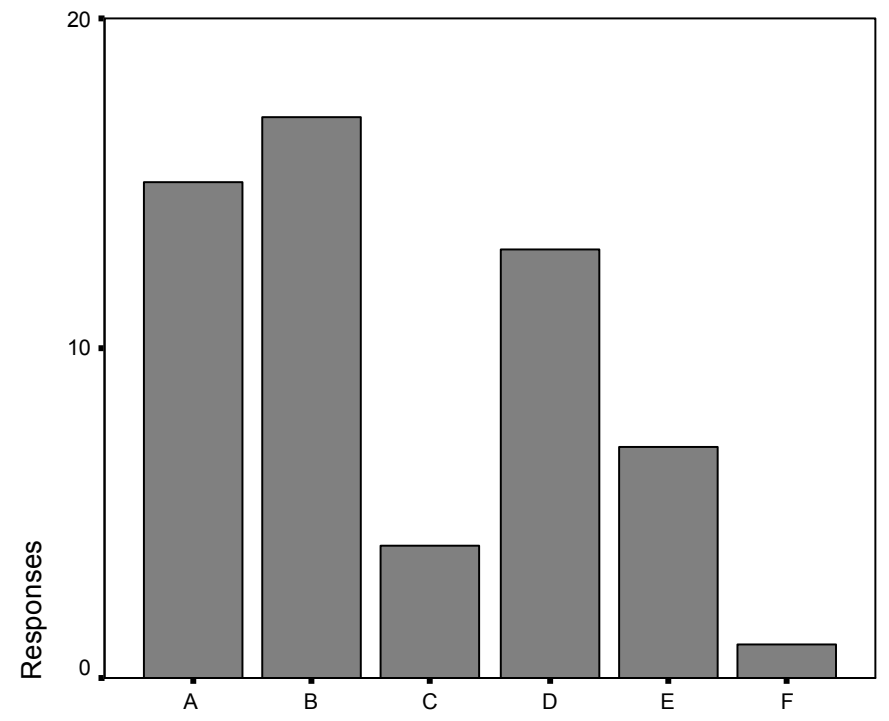

Key: No participants responded with G.

Figure D4. Response to Diet Recall: Potatoes (Question 4).

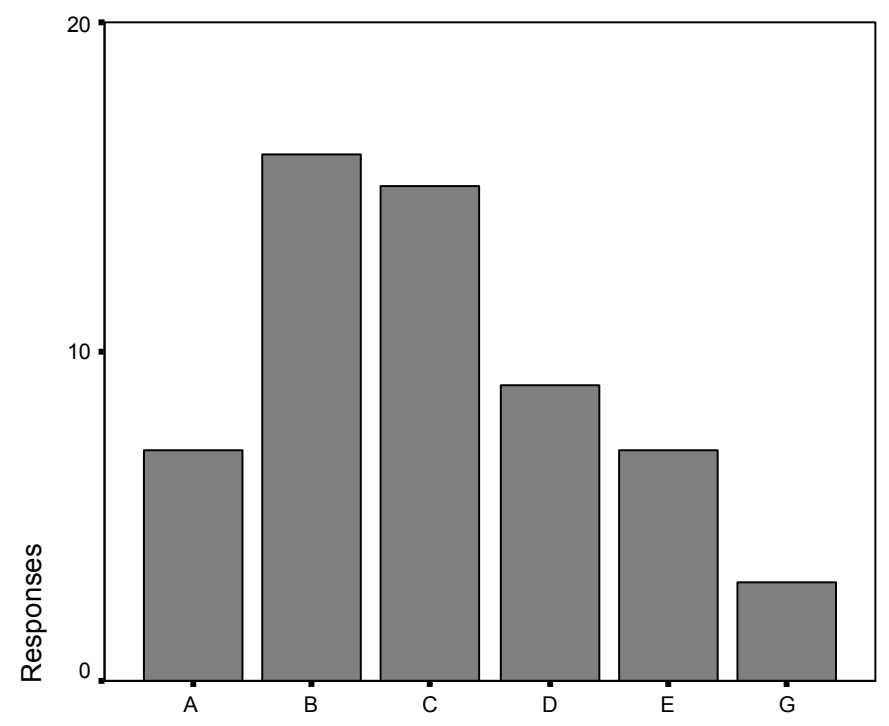

Key: No participants responded with F. 
Figure D5. Response to Diet Recall: Carrots (Question 5).

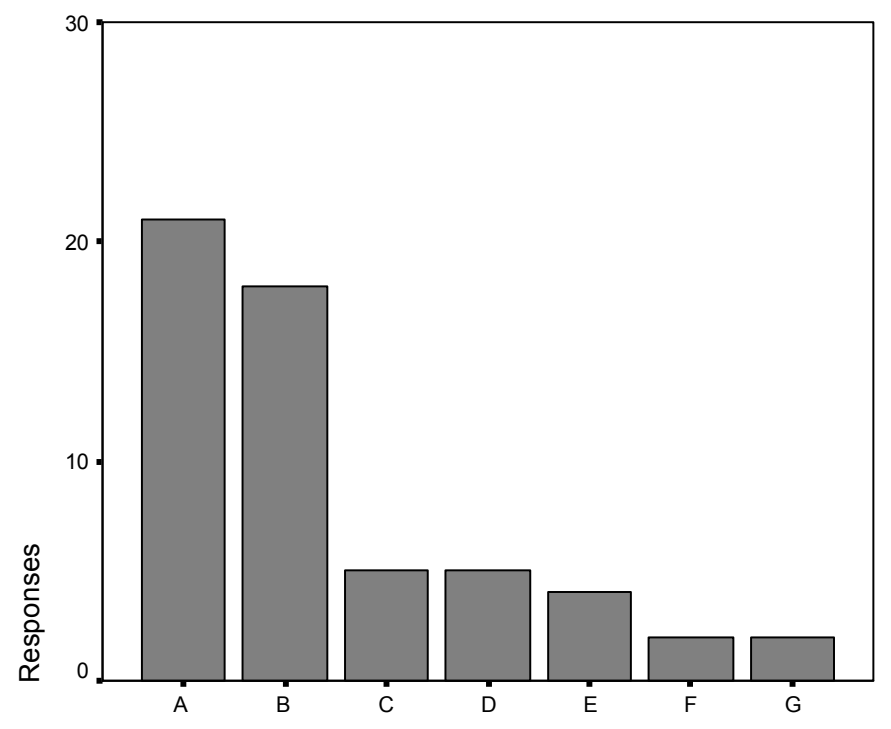

Figure D6. Response to Diet Recall: Other Vegetables (Question 6).

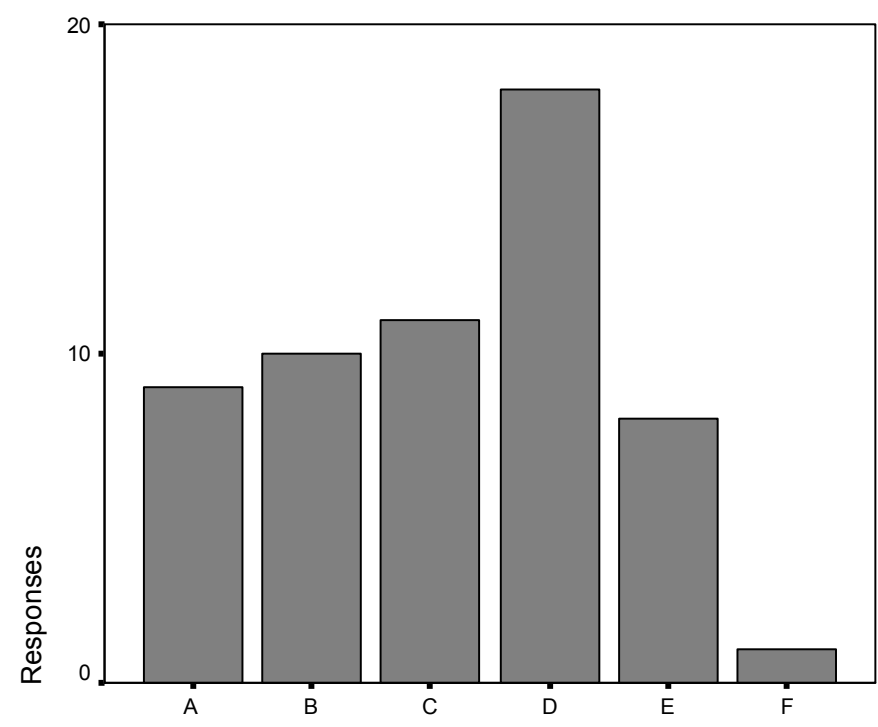

Key: No participants responded with G. 
Figure D7. Response to Diet Recall: Glasses of Milk (Question 7).

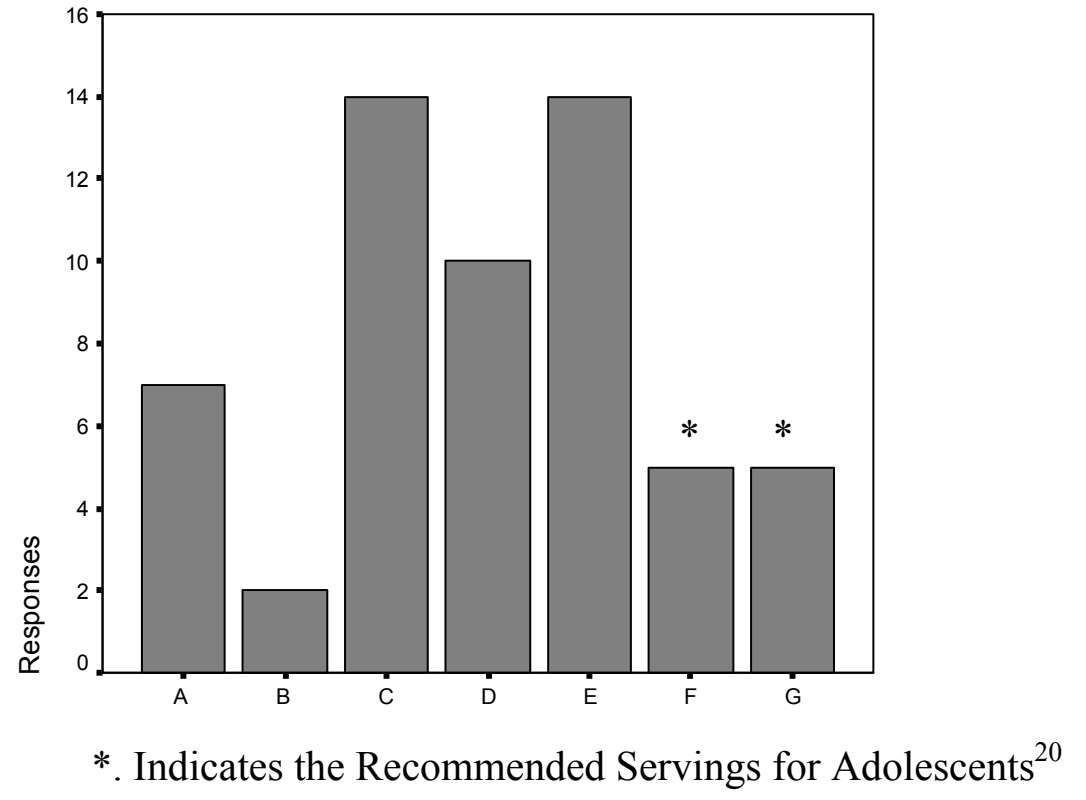

Figure D8. Response to Diet Recall: Chicken, Fish, or Red Meat (Question 8).

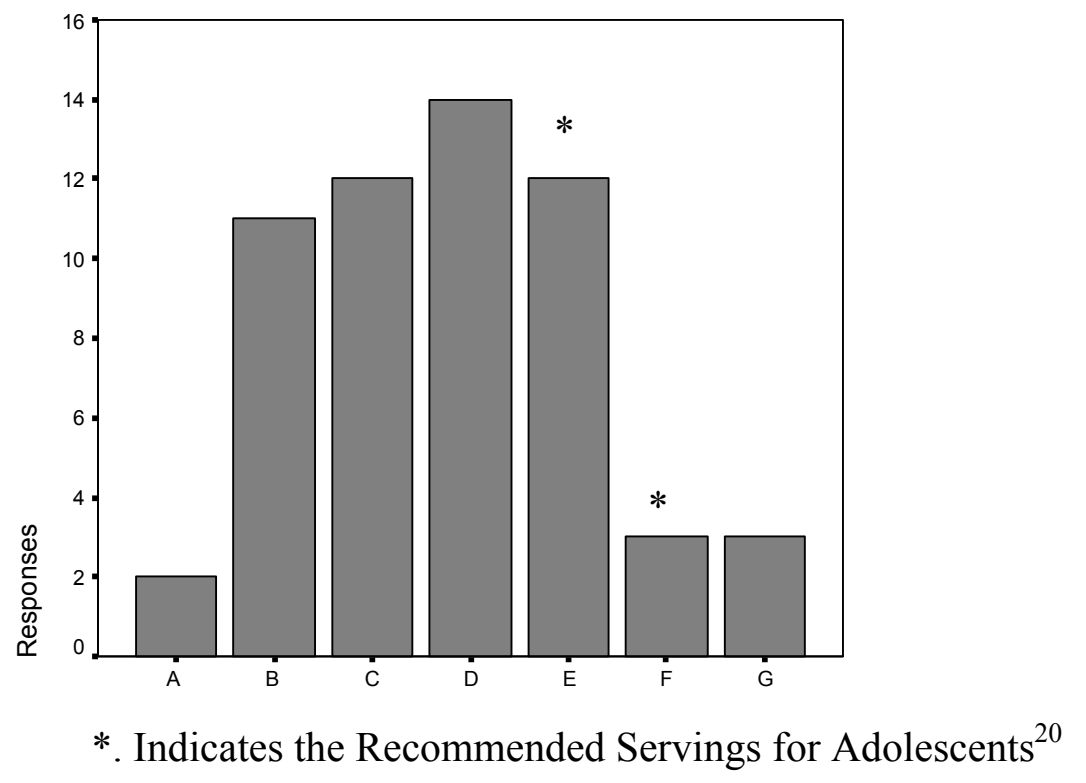


Figure D9. Response to Diet Recall: Other Types of Protein (Question 9).

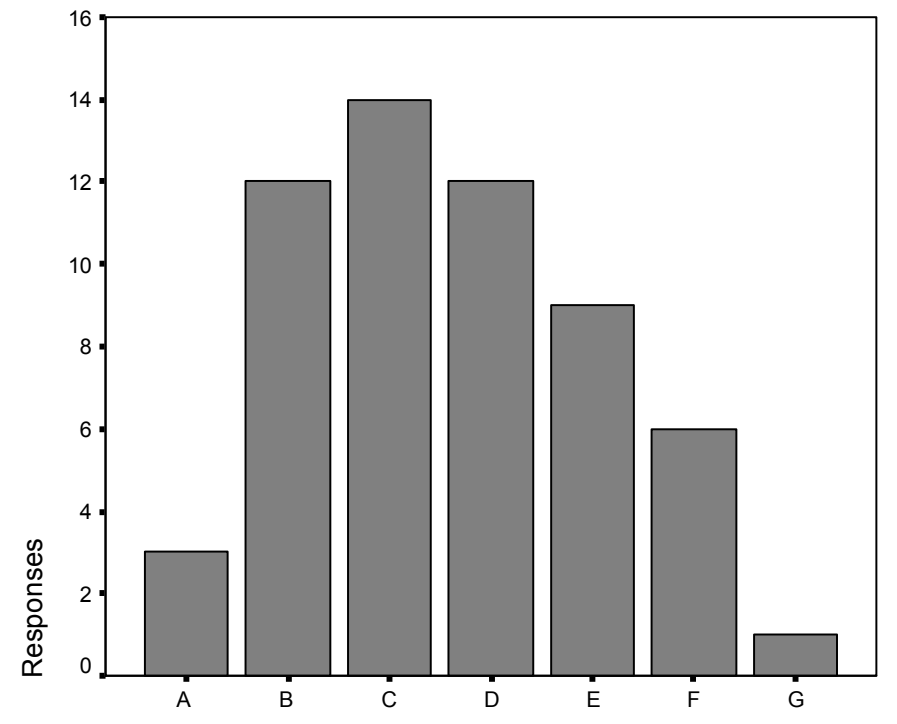

Figure D10. Response to Diet Recall: Bread or Cereal (Question 10).

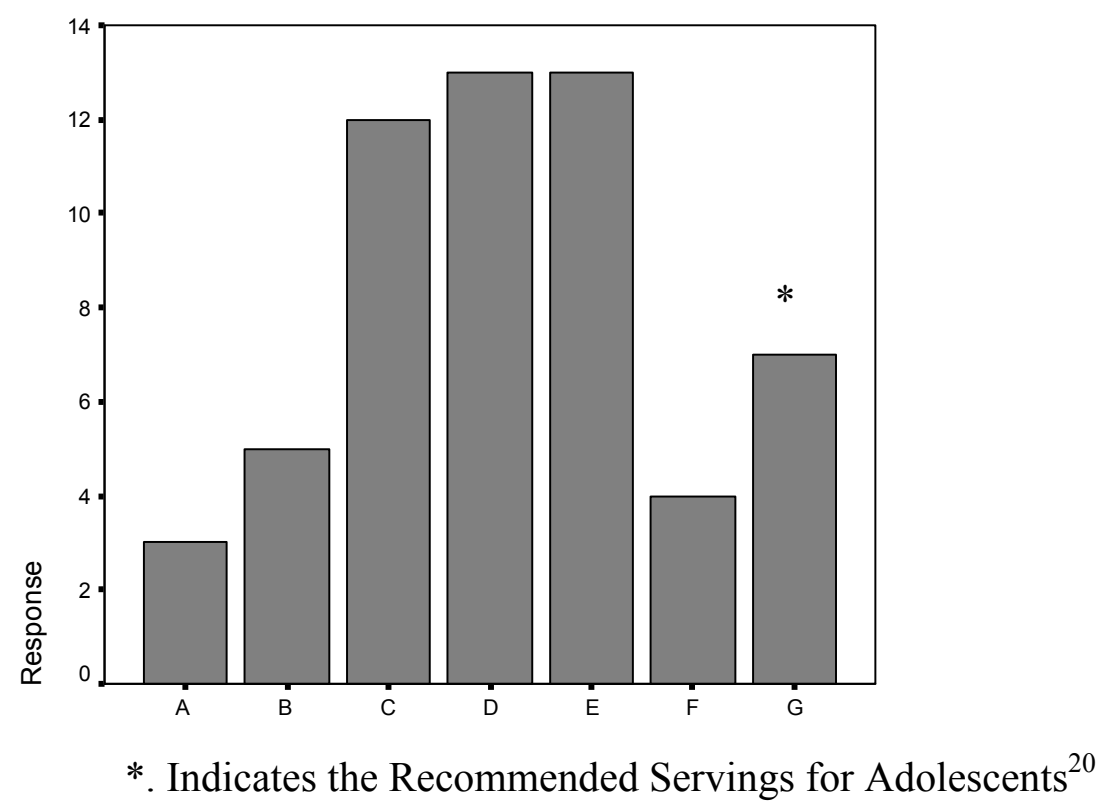


Figure D11. Response to Diet Recall: Other Types of Grains (Question 11).

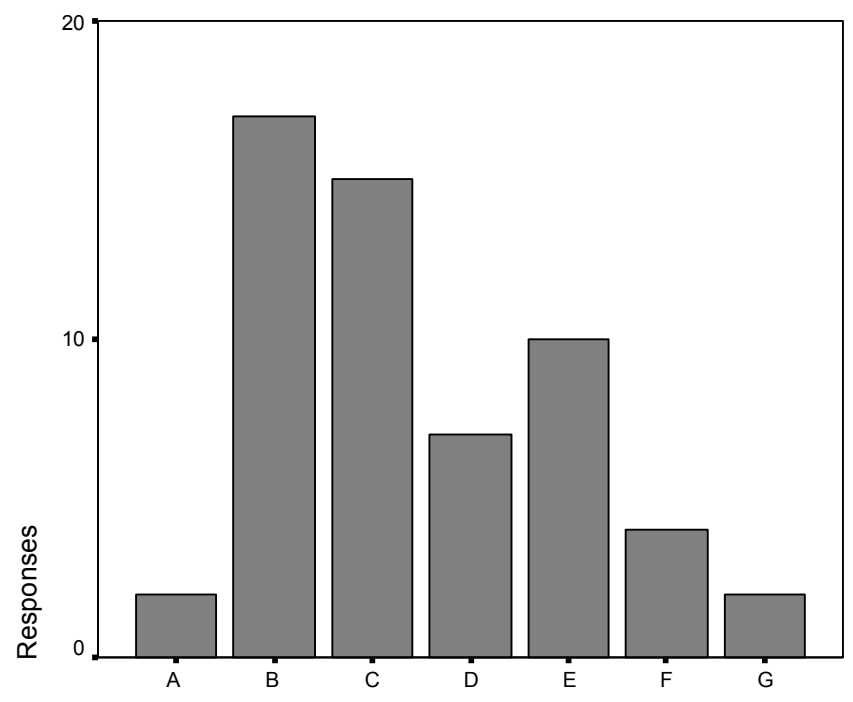

Figure D12. Response to Diet Recall: Fast Food (Question 12).

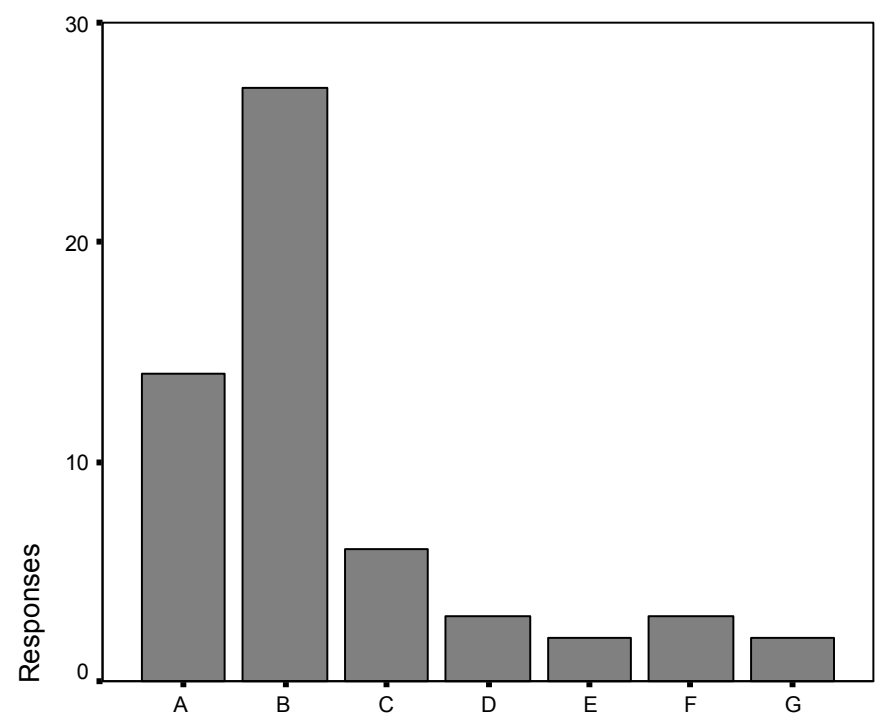


Figure D13. Response to Diet Recall: Glasses of Soda (Question 13).

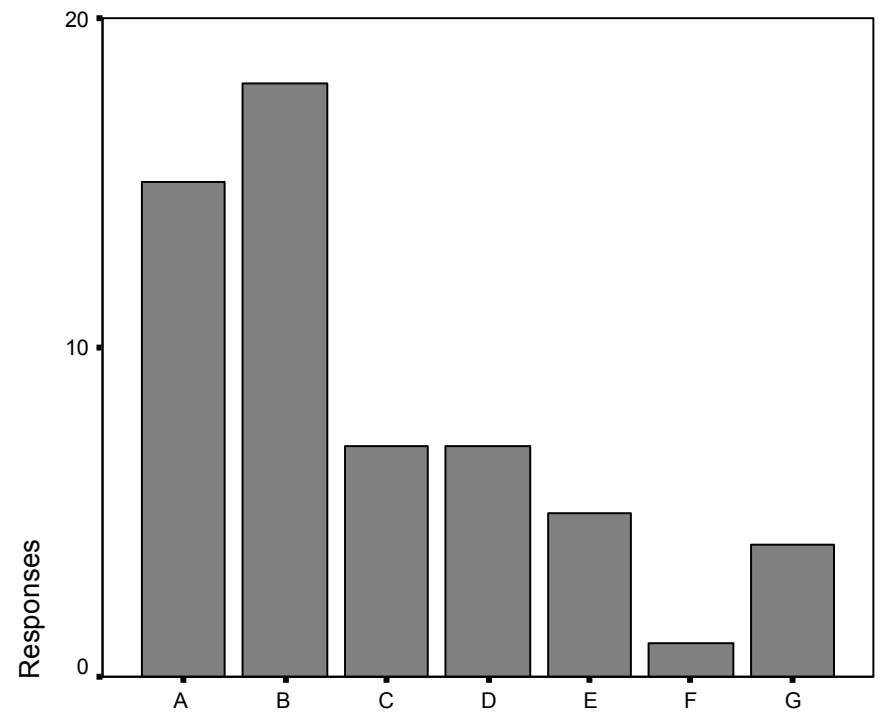

Figure D14. Response to Diet Recall: Junk Food (Question 14).

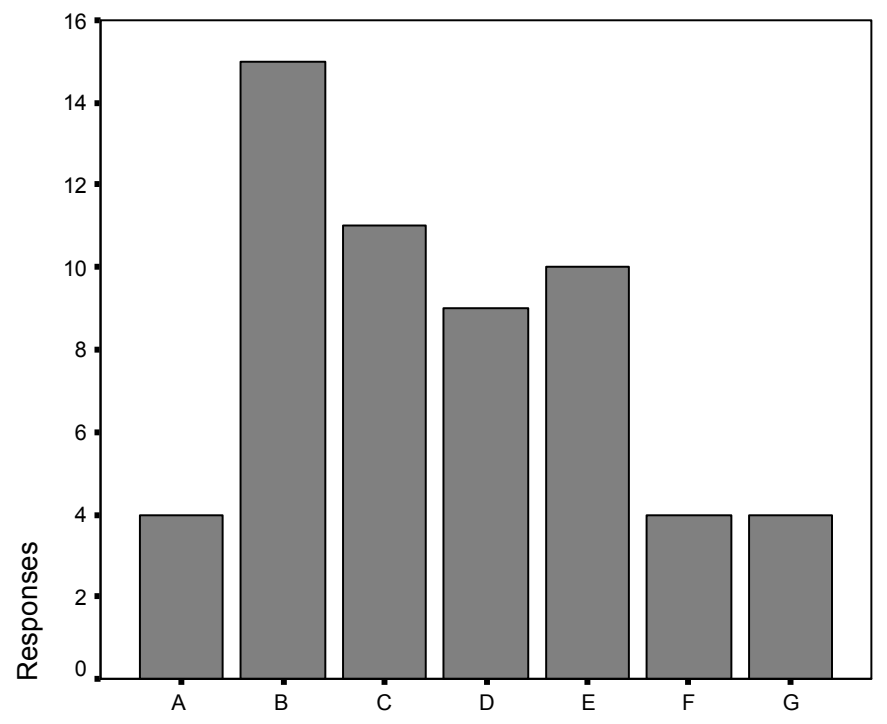


Figure D15. Response to Diet Recall: Water (Question 15).

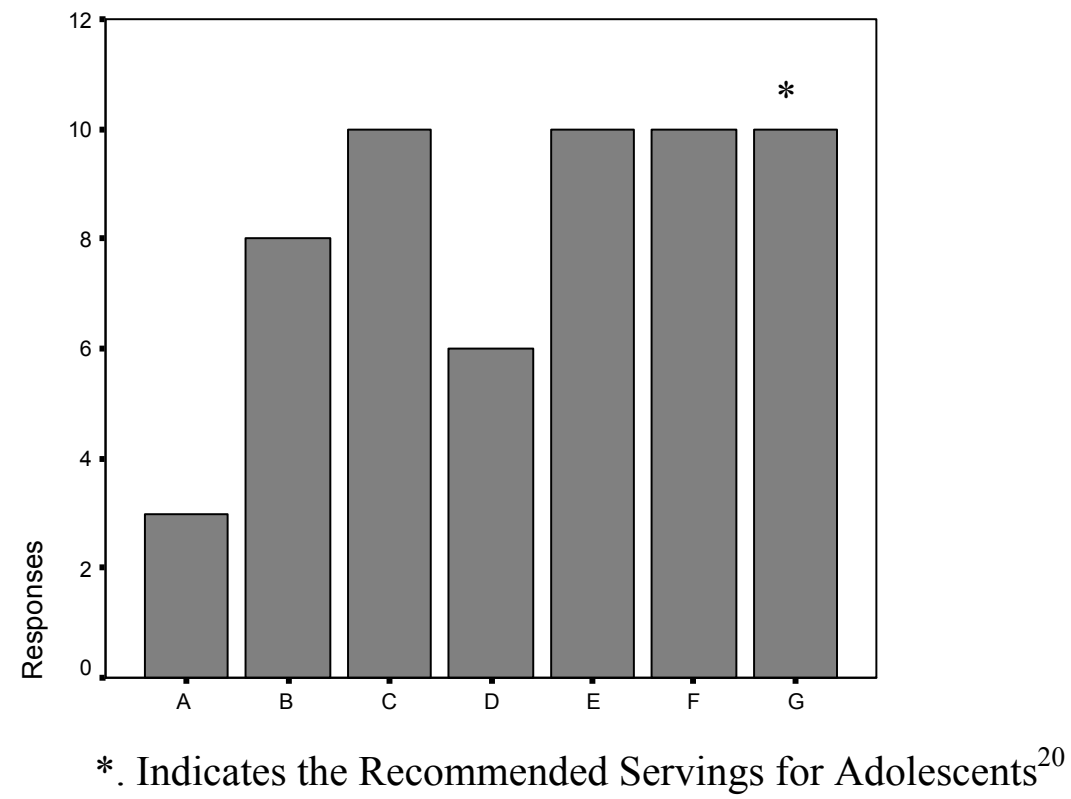




\section{APPENDIX E}

\section{RECOMMENDATIONS FOR FURTHER RESEARCH}

1. Repeat this study using a larger number of high school football players at different high schools in metropolitan and rural areas.

2. Modify the nutritional knowledge questionnaire to include the updated Food Guide Pyramid, if the nutrition/health class was taught during or after 2005.

3. Modify the diet recall to include the updated Food Guide Pyramid, if the nutrition/health class was taught during or after 2005.

4. Repeat this study using a 7-day food diary rather than the diet recall used in this study to make for a more accurate recall on the foods that were eaten by the participants.

5. Repeat this study on the nutritional knowledge questionnaire and diet recall using collegiate football athletes. 


\section{ADDITIONAL REFERENCES}

23. Clark N. Sports Nutrition Guidebook $2^{\text {nd }}$ ed. Brookline, MA. Human Kinetics 1997. 4-5,108,203.

24. American College of Sports Medicine; American Dietetic Association; Dietitians of Canada. Joint Position Statement: nutrition and athletic performance. American College of Sports Medicine, American Dietetic Association, and Dietitians of Canada. Med Sci Sports Exerc. 2000;32(12):2130-2145.

25. Kubik MY, Lytle LA, Story M. Soft drinks, candy, and fast food: what parents and teachers think about the middle school food environment. $\mathrm{J} \mathrm{Am}$ Diet Assoc. 2005;105(2):233-9.

26. Stang J, Story MT, Harnack L, Neumark-Sztainer D. Relationships between vitamin and mineral supplement use, dietary intake, and dietary adequacy among adolescents. J Am Diet Assoc. 2000;100(8):905-910.

27. Benardot D. Working with young athletes: views of a nutritionist on the sports medicine team. Int J Sport Nutr. 1996;6(2):110-120.

28. Rampersaud GC, Pereira MA, Girard BL, Adams J, Metzl JD. Breakfast habits, nutritional status, body weight, and academic performance in children and adolescents. J Am Diet Assoc. 2005;105(5):743-760.

29. Martin T, Martin J. Special issues and concerns for the high school and college-aged athletes. Pediatr Clin N Am. 2002;49:533-552.

30. Massad SJ, Shier NW, Koceja DM, Ellis NT. High school athletes and nutritional supplements: a study of knowledge and use. Int J Sport Nutr. $1995 ; 5(3): 232-245$.

31. Burns RD, Schiller MR, Merrick MA, Wolf KN. Intercollegiate sutednt athlete use of nutritional supplements and the role of athletic trainers and dietitians in nutrition counseling. J Am Diet Assoc. 2004;104:246-249.

32. Sobal J, Marquart LF. Vitamin/mineral supplement use among high school athletes. Adolescence. 1994;29(116):835-843.

33. Telford RD, Catchpole EA, Deakin V, Hahn AG, Plank AW. The effect of 7 to 8 months of vitamin/mineral supplementation on athletic performance. Int J Sport Nutr. 1992;2(2):135-153. 
34. Krumbach CJ, Ellis DR, Driskell JA. A report of vitamin and mineral supplement use among university athletes in a division I institution. Int $J$ Sport Nutr. 1999;9(4):416-425.

35. Schwartz NE. Nutritional knowledge, attitudes, and practices of high school graduates. J Am Diet Assoc. 1975;66(1):28-31.

36. Brook U, Tepper I. High school students' attitudes and knowledge of food consumption and body image: implications for school based education. Patient Educ Couns. 1997;30(3):283-288.

37. Burke L. Practical issues in nutrition for athletes. J Sports Sci. 1995;13 Spec No:S83-90.

38. West Virginia Department of Education. Health content standards and objectives for West Virginia schools. wvde.state.us/policies/p2520.5.doc . Accessed 7-21-05.

39. Singleton N. An assessment of the nutrition education of students in grades 3 to 12. J Am Diet Assoc. 1984;84(1):59-63.

40. Bingham SA. Limitations of the various methods for collecting dietary intake data. Ann Nutr Metab. 1991;35(3):117-127.

41. Magkos F, Yannakoulia M. Methodology of dietary assessment in athletes: concepts and pitfalls. Curr Opin Clin Nutr Metab Care. 2003;6(5):539-549.

42. Feskanich D, Rockett HR, Colditz GA. Modifying the healthy eating index to assess diet quality in children and adolescents. J Am Diet Assoc. 2004;10(9):1375-1383.

43. Nicklas T. Assessing diet quality in children and adolescents. J Am Diet Assoc. 2004;104(9):1383-1384. 